\title{
REVIEW
}

\section{Global review and inventory: how stable isotopes are helping us understand ecology and inform conservation of marine turtles}

\author{
Julia C. Haywood ${ }^{1,2, *}$, Wayne J. Fuller ${ }^{3}$, Brendan J. Godley ${ }^{1,4}{ }^{\text {, Jamie D. Shutler }}{ }^{5}$, \\ Stephen Widdicombe ${ }^{2}$, Annette C. Broderick ${ }^{1}$ \\ ${ }^{1}$ Marine Turtle Research Group, Centre for Ecology and Conservation, University of Exeter, Penryn Campus, Cornwall, \\ TR10 9FE, UK \\ ${ }^{2}$ Plymouth Marine Laboratory, Prospect Place, West Hoe, Plymouth, PL1 3DH, UK \\ ${ }^{3}$ Faculty of Veterinary Medicine, Near East University, North Cyprus, Mersin 10, Turkey \\ ${ }^{4}$ Environment and Sustainability Institute, University of Exeter, Penryn Campus, Cornwall, TR10 9FE, UK \\ ${ }^{5}$ Centre for Geography and Environmental Science, University of Exeter, Penryn Campus, Cornwall, TR10 9FE, UK
}

\begin{abstract}
Stable isotope analysis (SIA) has become a powerful and widely utilised tool in ecological studies, and more specifically has been used to answer conservation questions regarding key marine indicator species including marine turtles. Undertaking an exhaustive review of peerreviewed literature, we summarise the current knowledge of marine turtle spatial, foraging, and reproductive ecology gained through stable isotope studies and highlight the considerable flexibility and ecological complexities in the life histories of the six species that have been studied. We demonstrate how SIA can inform conservation initiatives, identify threats faced, and provide preand post-disaster information that is otherwise unavailable. We summarise isotope ratios at a global scale and demonstrate intraspecific regional differences and interspecific overlap. We identify the geographical gaps in the current knowledge and the bias in the species studied. To facilitate future research we identify a comprehensive list of recommendations including the need for standardised protocols for tissue collection and analysis; the use of a third forensic marker to provide greater power of inference; combining complementary techniques to enhance the information gained; conducting long-term research; and a need for meta-analytic approaches to combine research findings to better understand the complexities of marine turtle ecology. This review provides a complete list of all published marine turtle stable isotope studies which are summarised in an open access inventory to enable researchers to add new studies and target future work.
\end{abstract}

KEY WORDS: SIA $\cdot \delta^{13} \mathrm{C} \cdot \delta^{15} \mathrm{~N} \cdot$ Sea turtle $\cdot$ Foraging ecology $\cdot$ Migratory connectivity $\cdot$ Reproductive ecology $\cdot$ Threats

\section{INTRODUCTION}

\subsection{Background}

As a group of large marine vertebrates found widely throughout the temperate and tropical oceans, marine turtles can be considered as key indicator

\footnotetext{
*Corresponding author: julia.haywood@exeter.ac.uk
}

species of ecosystem function and health. Marine turtles have complex life histories (Miller 1997, Musick \& Limpus 1997, Plotkin 2003), often with multiple ontogenetic shifts in habitat and diet (e.g. Snover et al. 2008), and migrations of considerable distances between foraging and nesting grounds (e.g. James et al. 2005, Shillinger et al. 2008). Within one nesting

(C) The authors 2019. Open Access under Creative Commons by Attribution Licence. Use, distribution and reproduction are unrestricted. Authors and original publication must be credited. 
aggregation, several geographically distinct foraging areas may be utilised and different life history strategies may be employed (e.g. Hays et al. 2006, Seminoff et al. 2008, Dujon et al. 2018). Understanding the complex life histories of marine turtles and identifying critical habitats is a research priority in marine turtle ecology (Hamann et al. 2010, Rees et al. 2016, Casale et al. 2018).

Techniques to determine the movements of these elusive species include flipper tagging (e.g. Limpus et al. 1992, Hays et al. 2010), satellite telemetry (e.g. Nichols et al. 2000, Hays et al. 2006, Jeffers \& Godley 2016), and genetics (e.g. Shamblin et al. 2017). Flipper tagging requires large numbers to be tagged for successful recapture and offers no locational information between captures. Satellite telemetry is extensively used in marine turtle spatial ecology, offering detailed movement data on location and speed; however, this technique is expensive and often results in small sample sizes, limiting knowledge of population level behaviour (Godley et al. 2008). Genetics can, for example, identify connectivity between rookeries and foraging grounds but genetic studies can require broad geographic regions to be sampled (Avise 2007, Komoroske et al. 2017).

For successful conservation, it is important to protect not only the critical habitats of marine turtles but also the prey items on which they rely. Marine turtle dietary studies have historically relied on directly observing foraging behaviour (e.g. Ogden et al. 1983, Schofield et al. 2006), stomach content analysis at necropsy of stranded animals or oesophageal lavage (e.g. Seminoff et al. 2002, Santos et al. 2011), or using animal-borne cameras (e.g. Heithaus et al. 2002, Seminoff et al. 2006b, Fuller et al. 2009, Narazaki et al. 2013, Fukuoka et al. 2016, Thomson et al. 2018). Although these techniques allow for the taxonomic identification of prey items, direct observations of foraging behaviour are logistically difficult and in many cases not possible (Narazaki et al. 2013). Stomach content analysis represents a short dietary time frame and biases against rapidly digested softbodied prey (Duffy \& Jackson 1986, Heithaus et al. 2002), whilst animal-borne camera studies are limited by adequate light, battery and storage capabilities, and generally small sample sizes (Moll et al. 2007, Narazaki et al. 2013).

\subsection{Stable isotope analysis}

Stable isotope analysis (SIA) can be a powerful tool that can complement the aforementioned methods that evaluate foraging ecology and habitat use. SIA has been used in ecological studies for a range of marine taxa that are of conservation concern (Rubenstein \& Hobson 2004), including marine mammals (e.g. Newsome et al. 2010), elasmobranchs (e.g. Shiffman et al. 2012, Bird et al. 2018), and seabirds (e.g. Forero \& Hobson 2003, Roscales et al. 2011). Over the last two decades SIA has become an important tool for investigating marine turtle spatial, foraging, and reproductive ecology, highlighting ecological complexities in life history strategies and enhancing conservation approaches (e.g. Ceriani et al. 2017, Reich et al. 2017, Burgett et al. 2018). The isotopes of an element have different atomic weights, which react at differing rates. This leads to natural isotope gradients in environmental \& biological systems. SIA relies on measuring these isotope ratios. The ratio of stable isotopes in low-metabolically active tissue of an individual closely relates to the food it has consumed and the geographical location where it was ingested (DeNiro \& Epstein 1978, 1981). Most commonly, the ratios of ${ }^{13} \mathrm{C}:{ }^{12} \mathrm{C}$ (expressed as $\delta^{13} \mathrm{C}$ ) and ${ }^{15} \mathrm{~N}:{ }^{14} \mathrm{~N}$ (expressed as $\delta^{15} \mathrm{~N}$ ) are used as geographic markers resultant from variations in nutrient cycling within the water experienced by the individual (Graham et al. 2010).

The isotope ratio itself represents a time-integrated diet (Peterson \& Fry 1987), can be conducted on all life stages, and the analysis is cost effective (approximately £9-15 per sample dependent on the element to be analysed), allowing for large sample sizes. Different tissue types have different residence times; for example, blood serum has a short half-life and therefore represents food consumed recently, whilst epidermis has a longer half-life and therefore represents the diet consumed several months prior (Reich et al. 2008). Therefore, by assessing different tissue types, assessment of diet at multiple time points can be conducted (e.g. Petitet \& Bugoni 2017, Turner Tomaszewicz et al. 2017b).

Carbon isotope ratios reflect the primary producer responsible for the energy flow in the food chain (DeNiro \& Epstein 1978, Hobson 1987). Productive benthic and nearshore regions supported by algae and seagrass exhibit higher $\delta^{13} \mathrm{C}$ values in comparison to less productive pelagic and oceanic regions supported by phytoplankton (DeNiro \& Epstein 1978, Graham et al. 2010).

With regards to phytoplankton-driven food webs, temperature primarily drives the geographical and temporal variation of $\delta^{13} \mathrm{C}$ values, especially at higher latitudes, due to its influence on $\mathrm{CO}_{2}$ uptake rates, dissolved $\mathrm{CO}_{2}$ concentrations, and phytoplankton growth rates and community composition (Goer- 
icke \& Fry 1994, Hinga et al. 1994, Gruber et al. 1999, Graham et al. 2010, Magozzi et al. 2017). Phytoplankton shape, size, and species influences isotopic fractionation and results in regional-scale differences in $\delta^{13} \mathrm{C}$ values, for example between nearshore and offshore regions (Hinga et al. 1994, Pancost et al. 1997, Popp et al. 1998).

The $\delta^{15} \mathrm{~N}$ values in marine primary producers differs with (1) $\delta^{15} \mathrm{~N}$ values of their nutrient sources (e.g. nitrate, ammonium, and $\mathrm{N}_{2}$ ), (2) nitrogen-based processes, including $\mathrm{N}_{2}$-fixation, denitrification, and nitrification, and (3) isotopic fractionation (Montoya 2007). Areas of $\mathrm{N}_{2}$-fixation support primary producers with low $\delta^{15} \mathrm{~N}$ values as the $\delta^{15} \mathrm{~N}$ value of dissolved $\mathrm{N}_{2}$ is near $0 \%$ with little isotopic fractionation during its biological uptake (Dore et al. 2002, Montoya et al. 2002, Montoya 2007). In comparison, denitrification removes ${ }^{15} \mathrm{~N}$-depleted nitrate $\left(\mathrm{NO}_{3}{ }^{-}\right)$, leaving strongly ${ }^{15} \mathrm{~N}$-enriched nitrate and in turn primary producers with high $\delta^{15} \mathrm{~N}$ values (Voss et al. 2001, Dore et al. 2002). Large-scale spatial variation of phytoplankton $\delta^{15} \mathrm{~N}$ values is driven by the upwelling of ${ }^{15} \mathrm{~N}$-enriched nitrate as a result of denitrification at depth (Graham et al. 2010). Anthropogenic waste and agricultural runoff in coastal habitats increase the $\delta^{15} \mathrm{~N}$ values in particulate matter used by primary producers (Harrington et al. 1998, McKinney et al. 2002). These spatial variations are reflected in higher trophic consumers and can therefore be used as a marker for habitat use on large scales.

Nitrogen isotope ratios in individuals have also been used to reflect trophic patterns (DeNiro \& Epstein 1978, 1981). It has been suggested that in marine ecosystems, a 3 to $4 \%$ step-wise enrichment of $\delta^{15} \mathrm{~N}$ values occurs in each subsequent trophic level as ${ }^{15} \mathrm{~N}$ retention is higher than ${ }^{14} \mathrm{~N}$ (Minagawa \& Wada 1984, Post 2002). However, due to the many factors influencing isotope ratios this distinction is sometimes not straightforward (see Section 3.5 on limitations of this method). Previous work using compound-specific SIA (CSIA) of amino acids on marine turtles has shown variations in $\delta^{15} \mathrm{~N}$ values are due to shifts in baseline isotope ratios and not trophic position (Seminoff et al. 2012, Vander Zanden et al. 2013a; see Section 3.6 for details on CSIA).

Spatial and temporal variation in $\delta^{13} \mathrm{C}$ and $\delta^{15} \mathrm{~N}$ values in marine phytoplankton is large, consistent and relatively well understood, to the extent that mechanistic models can capture most of the observed variance (e.g. Tagliabue \& Bopp 2008, Somes et al. 2010, Schmittner \& Somes 2016, Magozzi et al. 2017). These realistic predictions of baseline isotope ratios improve the interpretation of $\delta^{13} \mathrm{C}$ and $\delta^{15} \mathrm{~N}$ values in marine organisms as geolocation tools (Graham et al. 2010, McMahon et al. 2013, Magozzi et al. 2017).

Stable isotope ratios of other elements, including sulphur $\left(\delta^{34} \mathrm{~S}\right)$ and oxygen $\left(\delta^{18} \mathrm{O}\right)$, have also been used in marine turtle studies. $\delta^{34} \mathrm{~S}$ values differ between primary producers in sulphide-rich sediments and those with limited access to sulphide (Sullivan \& Moncreiff 1990). Therefore, $\delta^{34} \mathrm{~S}$ values can be used to differentiate between ecosystems supported by seagrass and microphytobenthos, which have low $\delta^{34} \mathrm{~S}$ values, and ecosystems supported by phytoplankton and macroalage, which have high $\delta^{34}$ S values (e.g. Cardona et al. 2009, Bradshaw et al. 2017). $\delta^{18} \mathrm{O}$ values reflect water temperature when applied to biominerals such as bones or the epifaunal barnacles on the carapace of a turtle (e.g. Killingley \& Lutcavage 1983, Detjen et al. 2015).

\subsection{Current review}

SIA has been used in marine turtle research since 1983 (Killingley \& Lutcavage 1983) and has provided an extensive range of insights into marine turtle ecology. Pearson et al. (2017) reviewed SIA data of marine turtles, but their objectives were to highlight the bias of marine turtle stable isotope studies towards populations listed by the IUCN (International Union for Conservation of Nature) as Least Concern.

In this review we compile the current insights into marine turtle ecology and conservation gained through SIA, highlight gaps in existing knowledge, and suggest future recommendations for the preparation and interpretation of SIA in marine turtle research. We also combine all published isotope ratios to summarise these data on a global scale. An accessible inventory of all marine turtle stable isotope research is also included to enable researchers to add new studies, target future work, and help prevent unnecessary research overlaps in the future (see the data archived at https://doi.org/10.1594/PANGAEA. 892683).

\section{METHODOLOGY}

We conducted a systematic review to determine the ecological insights gained from marine turtle stable isotope studies and determine the current gaps in this field. An extensive literature search was conducted in English (Scopus, Web of Science, and Google Scholar; last accessed $31^{\text {st }}$ December 2018). The terms searched were, 'sea turtle', 'marine turtle', 
'loggerhead turtle', 'green turtle', 'leatherback', 'hawksbill', 'Kemp's ridley', 'olive ridley', 'flatback', and 'isotope' in TITLE-ABSTRACT-KEYWORDS for Scopus and TOPIC for Web of Science. The top 200 papers in Google Scholar were ranked by relevance and suitable literature was selected. All peer-reviewed primary research papers were included in the analysis excluding fossil isotope studies.

From each study, isotope ratios were extracted either (1) directly from text, (2) from supplemental raw values, (3) from the range provided, (4) from a graph that provided a mean, or (5) from a scatter plot, in which case the mid-value from the range was determined by eye. Additional information including the location of the study, tissue type utilised, life stage, species, and methodology was extracted (collated, see the data archived at https://doi.org/10. 1594/PANGAEA.892683). If life stage was unknown it was not included in the interspecies and ocean basin isotope ratio comparisons (see Sections 3.2.2 and 3.2.3). If multiple tissue-types were sampled for an individual only the epidermal isotope ratio was selected to be included in the analysis. Samples from the Atlantic Ocean were further separated into the main Atlantic basin, Gulf of Mexico, Caribbean Sea, or subtropical Northwest Atlantic (SNWA) due to previously published differences in isotope ratios attributed to the spatial variation of isotope ratios at the base of the food web rather than dietary differences (Pajuelo et al. 2012b, Vander Zanden et al. 2013a, 2015, 2016, Tucker et al. 2014, Ceriani et al. 2017). For example, nutrient-rich waters and denitrification in the Gulf of Mexico could cause higher $\delta^{15} \mathrm{~N}$ values in this region compared to the SNWA and
Caribbean Sea, which is influenced by nitrogen fixation (Vander Zanden et al. 2015). The SNWA had high $\delta^{13} \mathrm{C}$ values, which was suggested to be due to being a seagrass-dominated ecosystem compared to other regions likely supported by phytoplankton, macroalgae, and mangroves (Vander Zanden et al. 2015). Therefore these regions are represented separately within our analysis.

Our search results identified 114 published studies (46 since 2015) that investigated stable isotopes in marine turtles. The primary focus of 21 of these studies was on methodology whilst the remaining 93 were ecological studies (Table S1). Five methodological-based studies on captive individuals likely provided artefactual isotope ratios and were not included for geographic comparisons, however for completeness, details on these studies are available in the archived data at https://doi.org/10.1594/PANGAEA. 892683.

\section{RESULTS AND DISCUSSION}

\subsection{Overview of studies}

Compiling global isotope studies highlights gaps in current knowledge with a bias towards studying certain species and regions (Fig. 1 and Table 1). Loggerhead Caretta caretta and green turtles Chelonia mydas are the most studied whilst, as yet, there has been no published study on flatback turtles Natator depressus. Split by ocean basin, Fig. 1 shows that most studies were conducted in the Atlantic (55\%), followed by the Pacific (30\%), Mediterranean (10\%),

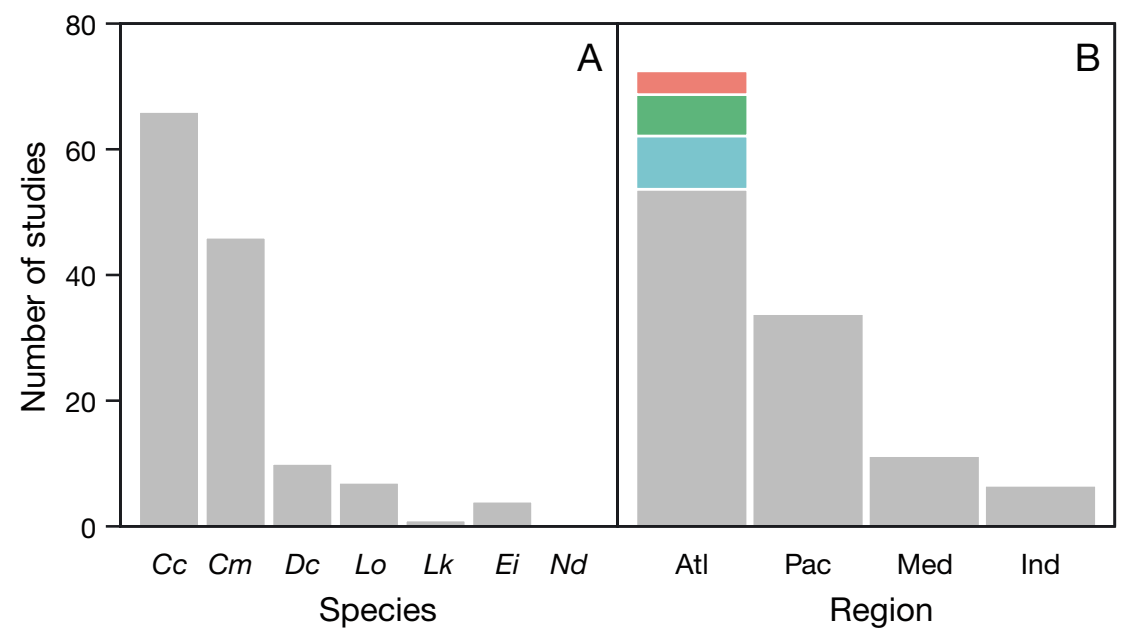

Fig. 1. Number of studies of stable isotopes in marine turtles by (A) species and (B) region. (A) $C_{C}$ : loggerhead turtle; $\mathrm{Cm}$ : green turtle; Dc: leatherback turtle; Lo: olive ridley turtle; Lk: Kemp's ridley turtle; Ei: hawksbill turtle; Nd: flatback turtle. (B) Atl: Atlantic Ocean (including subtropical Northwest Atlantic [red], Caribbean Sea [green] and Gulf of Mexico [blue]); Pac: Pacific Ocean; Med: Mediterranean Sea; Ind: Indian Ocean 


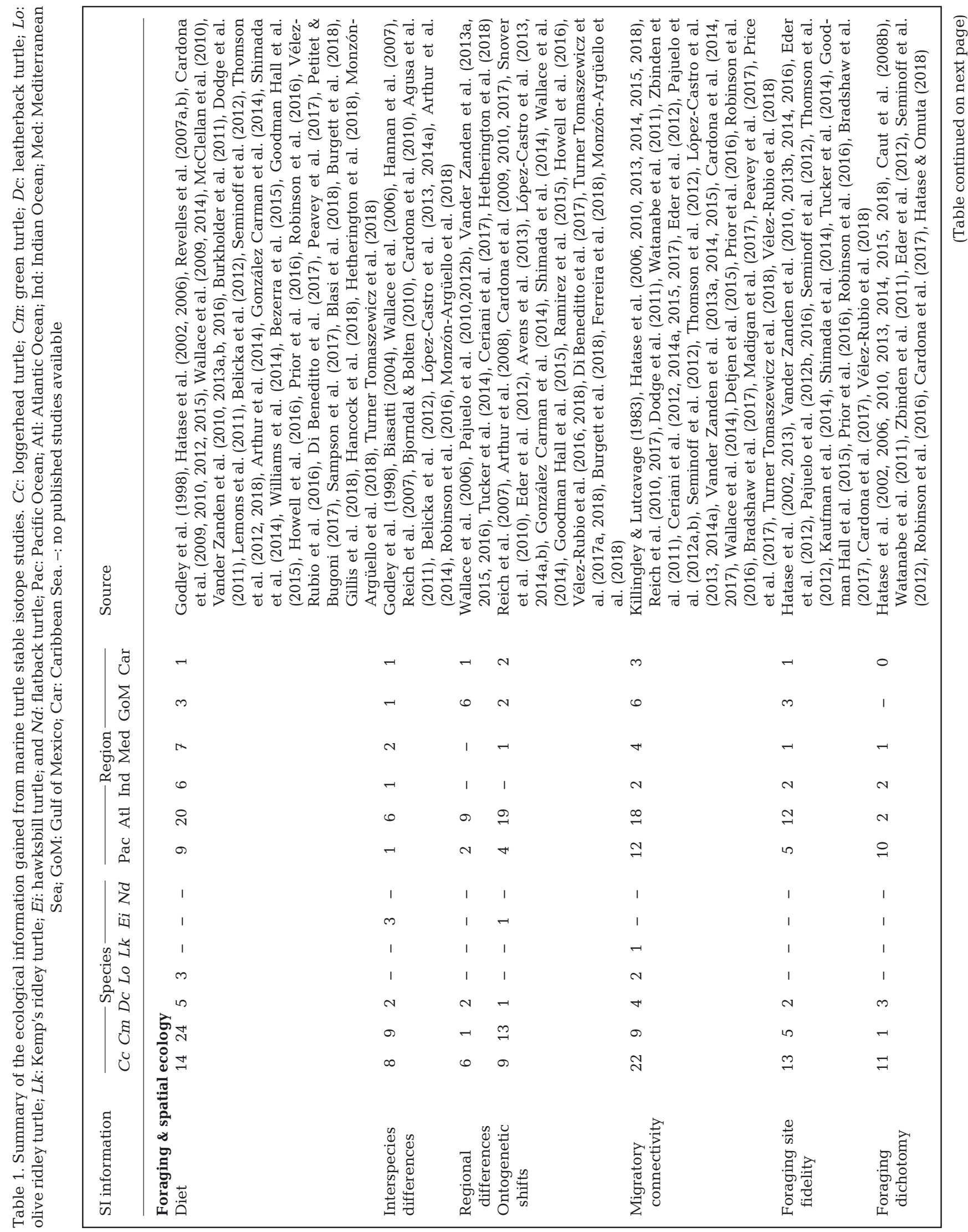




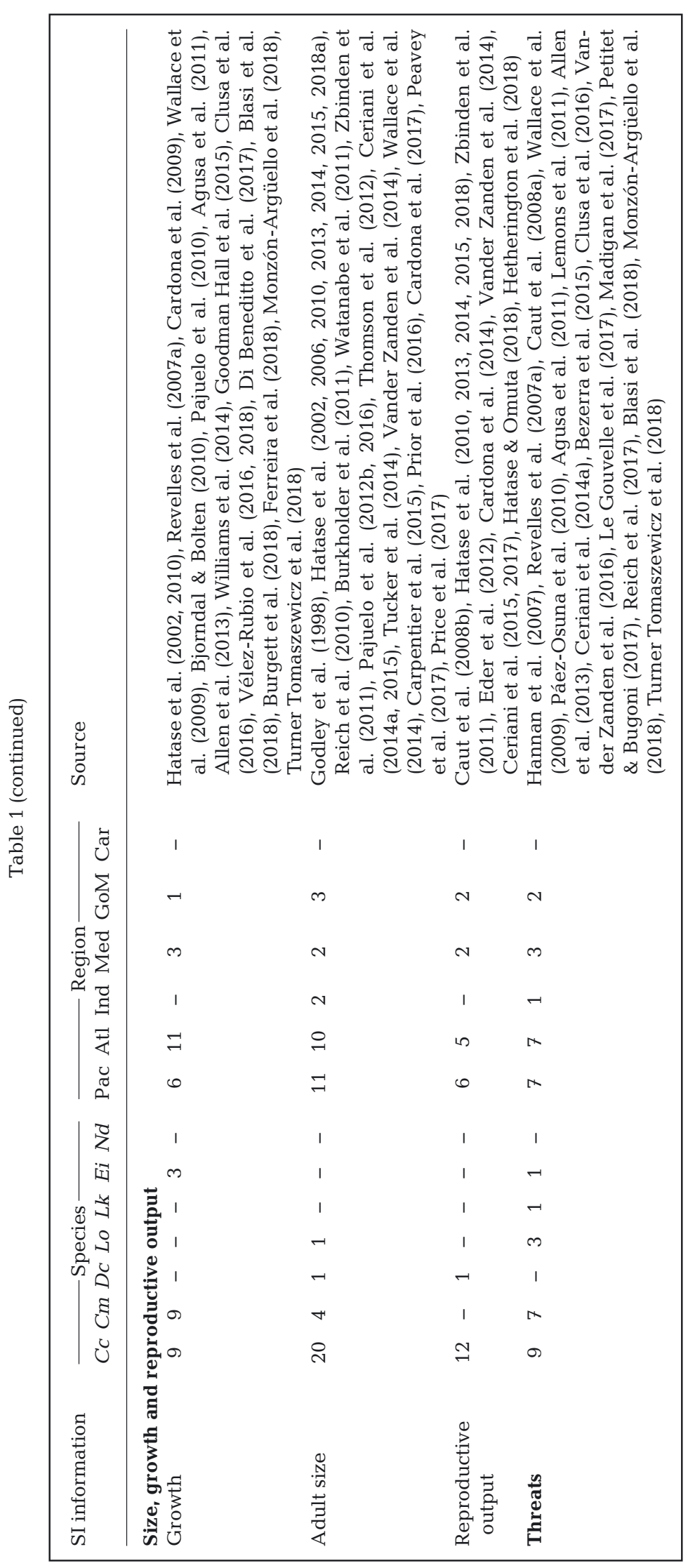

and Indian Ocean (5\%). Mapping the location of studies globally illustrates that there are large geographical gaps in marine turtle isotope research (Fig. 2), with $77 \%$ of studies carried out in six countries (USA $=47 \%$, Japan $=10 \%$, Spain $=6 \%$, Australia $=6 \%$, Brazil $=6 \%$, Mexico $=3 \%$ ). This geographical bias is unsurprising as current SIA research is conducted on well-studied populations, and some areas of a species' range are inaccessible, especially species with restricted nesting habitats, e.g. flatback turtles.

We show that adult females were sampled most frequently ( $44 \%$, including studies that sampled hatchlings and eggs as a proxy for maternal tissue), followed by juveniles $(40 \%)$, and adult males $(16 \%$; Table S1 in the Supplement at www.int-res.com/articles/ suppl/m613p217_supp.xlsx). A large range of tissue types have been sampled with epidermis sampled the most frequently $(30 \%)$, followed by scute (carapace, $15.5 \%$ ), egg yolk $(9 \%)$, red blood cells $(9 \%)$, humeri $(7.5 \%)$, blood plasma $(7 \%)$, muscle $(6 \%)$, whole blood $(6 \%)$, whole egg (albumen and yolk, 2\%), blood serum $(2 \%)$, albumen $(1 \%)$, egg shell $(1 \%)$, embryos $(1 \%)$, epibionts $(1 \%)$, liver $(1 \%)$, and tendon $(1 \%)$.

These findings support the review by Pearson et al. (2017), who suggest that the focus of future work should be directed at under-studied species, for example flatback turtles, and we suggest more needs to be done globally across the full range and life stages of all species. Information on habitat use is important for all populations, particularly those less studied or those in highly disturbed areas.

\subsection{Foraging and spatial ecology}

Summarising marine turtle stable isotope studies demonstrated that the majority $(83 \%)$ have investigated foraging ecology specifics, including identifying foraging grounds, foraging site fidelity, and diet (Table 1). This is also the case for marine mammal and elasmobranch ecology where SIA is most commonly used to study diet and trophic position (Forero \& Hobson 2003, Newsome et al. 2010, Shiffman et al. 2012). Understanding the variation in foraging 

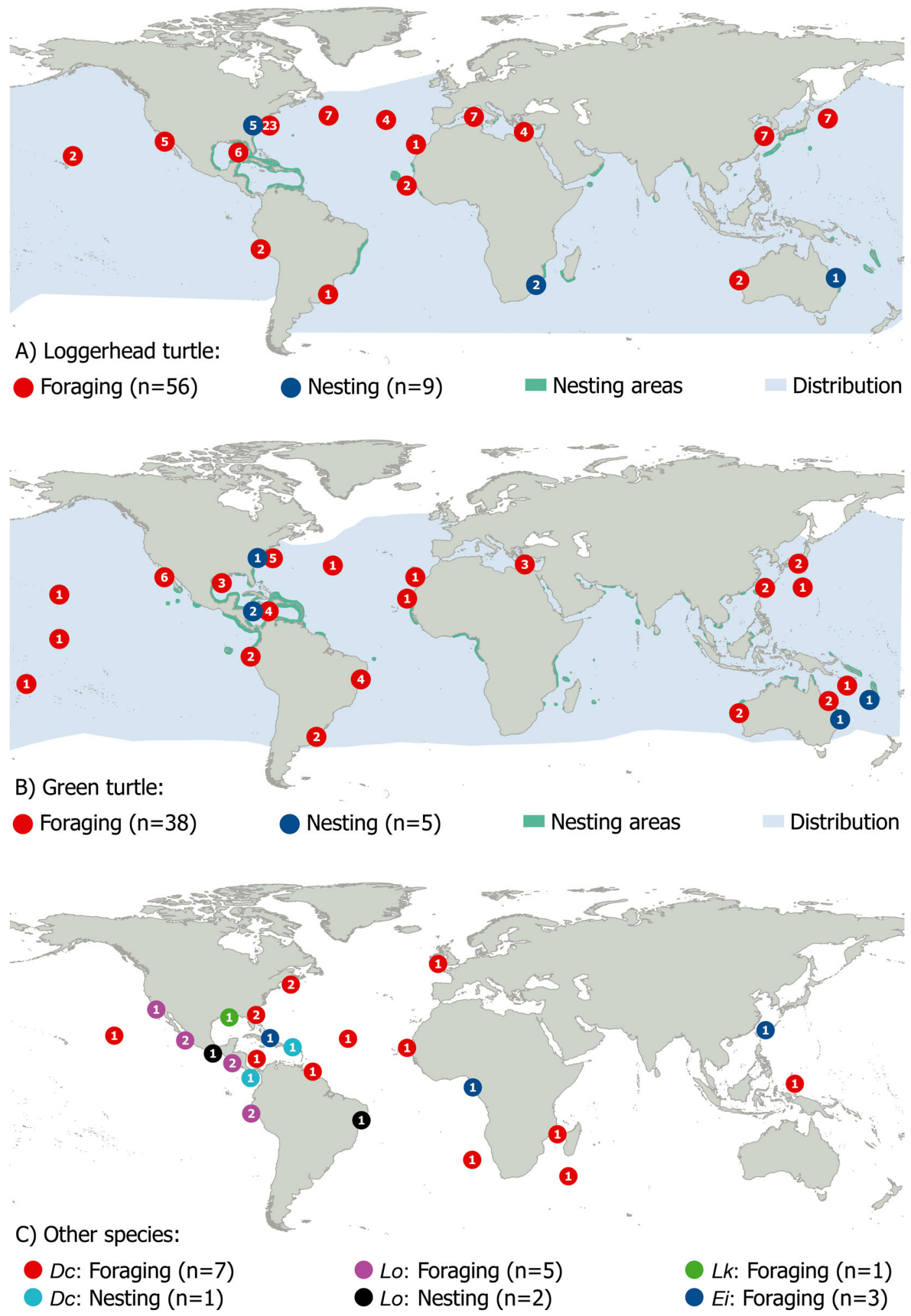

Fig. 2. Geographical location of studies investigating stable isotopes in marine turtles: (A) loggerhead turtle, (B) green turtle, and $(\mathrm{C})$ other species. For species abbreviations see Fig. 1. Points represent studies that investigated marine turtle isotope ratios from known foraging grounds or at nesting grounds when foraging grounds were not identified. Numbers within the points represent the number of studies. Loggerhead and green turtle distributions (blue) and nesting areas (green) are shown. Distributions adapted from IUCN and nesting areas from OBIS-Seamap 
strategies enables population-level questions to be answered, for example, individual variations in life history strategies and carry-over effects between foraging and breeding seasons (e.g. Caut et al. 2008b, Ceriani et al. 2017, Hatase et al. 2018). SIA also enables the demographic trends of a population to be better understood (e.g. Bradshaw et al. 2017) and the threats faced by a population (both environmental and anthropogenic) to be assessed (e.g. Clusa et al. 2016, Vander Zanden et al. 2016).

\subsubsection{Diet}

The proportion of prey items contributing to the diet of an individual can be estimated from their isotope ratio via isotope mixing models. See Section 3.6 for details and limitations of isotope mixing models. This is a major area of study in marine turtle research and has enabled the diet of several marine turtle populations to be estimated, showing the large variability in intra- and inter-species diets (Table 1). Isotope studies of adult and juvenile loggerhead turtles in neritic foraging grounds have shown that the dominant prey were benthic items such as molluscs and crustaceans (Hatase et al. 2002, Wallace et al. 2009, McClellan et al. 2010, Goodman Hall et al. 2015) whilst the dominant prey for individuals in oceanic foraging grounds were pelagic prey, for example macroplankton, including gelatinous zooplankton and jellyfish (Hatase et al. 2002, Revelles et al. 2007b, McClellan et al. 2010, Cardona et al. 2012).

Depending on the population, within neritic foraging grounds, adult and juvenile green turtles were suggested to consume macrophytes (Bezerra et al. 2015, Howell et al. 2016, Prior et al. 2016, Di Beneditto et al. 2017). However, SIA has shown the presence, and in some cases dominance of animal-based matter demonstrating omnivorous behaviour (Godley et al. 1998, Hatase et al. 2006, Cardona et al. 2009, 2010, Burkholder et al. 2011, Lemons et al. 2011, Belicka et al. 2012, González Carman et al. 2014, Shimada et al. 2014, Williams et al. 2014, Vélez-Rubio et al. 2016, Sampson et al. 2017, Burgett et al. 2018, Gillis et al. 2018, Hancock et al. 2018, Monzón-Argüello et al. 2018, Thomson et al. 2018, Turner Tomaszewicz et al. 2018). There is also evidence that adult green turtles forage from the water column in coastal regions (Turner Tomaszewicz et al. 2018) and on macroplankton in oceanic regions (Hatase et al. 2006).

Isotopes can also be used to infer both individual specialisation and the ecological niche of a species based on the intra- and inter-individual variation in isotope ratios (Newsome et al. 2007, Vander Zanden et al. 2010, 2013b, 2016, Burkholder et al. 2011, Lemons et al. 2011, Ferreira et al. 2018, Thomson et al. 2018). To estimate individual consistency and specialisation, analysis of variance techniques have been used (e.g. Vander Zanden et al. 2010, 2013b, 2016, Lemons et al. 2011), whilst to estimate isotopic niche width studies have used the Layman et al. (2007) total area metric (e.g. Burkholder et al. 2011) or Stable Isotope Bayesian Ellipses in R (SIBER, Jackson et al. 2011; e.g. Ferreira et al. 2018, Hancock et al. 2018). Using SIA, individual specialisation has been reported for other marine taxa including sharks (e.g. Matich et al. 2011) and marine mammals and penguins (e.g. Cherel et al. 2007). Understanding the diet resources used by a population enables temporal shifts to be monitored and it also informs conservation strategies allowing the targeting and management of the turtle foraging grounds and the diverse range of prey on which they rely.

\subsubsection{Global interspecies differences in isotope ratios}

Several studies have conducted SIA on multiple species (Table 1). For example, previous interspecies comparisons in isotope ratios showed adult loggerhead turtles had higher $\delta^{15} \mathrm{~N}$ values and in some cases lower $\delta^{13} \mathrm{C}$ values than green turtles, suggesting higher trophic level foraging (Godley et al. 1998, Hannan et al. 2007, Monzón-Argüello et al. 2018), whilst no differences were seen between oceanic loggerhead and juvenile green turtles, suggesting similar prey items and foraging locations (Reich et al. 2007, Cardona et al. 2010, López-Castro et al. 2013). One SIA study showed that adult leatherback turtles Dermochelys coriacea, differing from loggerhead and green turtles (Godley et al. 1998), have an oceanic foraging strategy, whilst a second study revealed an unexpected neritic foraging strategy of leatherback turtles in the Indian Ocean (Robinson et al. 2016).

Isotope studies have suggested minimal levels of interspecific competition in foraging resources between hawksbill Eretmochelys imbricate and green turtles in the Caribbean, with hawksbill turtles foraging at higher trophic levels (Bjorndal \& Bolten 2010). However, no differences have been reported between green and hawksbill turtles in Japan (Agusa et al. 2011). These contrasting findings are likely due to dietary difference. Further analysis could be performed to estimate differences in diet composition and trophic positions within these populations using 
mixing models and CSIA (see Section 3.6). SIA has been used to investigate interspecies differences in isotope ratios within other marine taxonomic groups including marine mammals (e.g. Burton \& Koch 1999, Newsome et al. 2010), seabirds (Forero \& Hobson 2003), penguins (Cherel et al. 2007), and elasmobranchs (e.g. Shiffman et al. 2012, Bird et al. 2018).

This review combines global marine turtle isotope ratios, demonstrating that clear species differences do not occur globally, for either adults or juveniles, with large overlapping interspecies ranges (Fig. 3, Table S1 in the Supplement). This is likely due to the many complex factors affecting isotope ratios (see Section 1.2) as well as ocean basin differences in baseline isotope ratios (see Section 3.2.3). For adults, green turtles were the most distinct species with low $\delta^{15} \mathrm{~N}$ and high $\delta^{13} \mathrm{C}$ values. Loggerhead turtles had intermediate isotope ratios whilst hawksbill, Kemp's ridley Lepidochelys kempii, leatherback, and olive ridley turtles Lepidochelys olivacea had similar mean values, with high $\delta^{15} \mathrm{~N}$ and low $\delta^{13} \mathrm{C}$ values. Within juveniles, green and hawksbill turtles had low $\delta^{15} \mathrm{~N}$ and high $\delta^{13} \mathrm{C}$ values in comparison to the other species. Only single studies investigated adult hawksbill and Kemp's ridley turtles and juvenile leatherback and olive ridley turtles and therefore do not represent their global isotope ratios. In addition, the ratios used for these analyses stemmed from multiple tissue types that were preserved and prepared with different techniques, which can affect isotope results (see Section 3.7).

When we further split the global data by ocean basin, different interspecies relationships are shown
(Fig. S1 in the Supplement). This is unlikely due to distinct intraspecies differences in foraging strategy across ocean basins, but rather due to local variations in isotope ratios at the base of the food chain of the sampled populations.

\subsubsection{Ocean basin differences in isotope ratios}

The majority of studies to date focus on individual populations in specific regions, whilst few studies have investigated how a species' isotope ratios differ between ocean basins (Table 1). In this review we compiled ocean basin isotope ratios for each species and show that the large intraspecies ranges previously observed (see Section 3.2.2) are likely partly due to geographical variation (Fig. 4, Table S1 in the Supplement; for other species plots see Fig. S2 in the Supplement). We show that adult loggerhead turtles foraging in the SNWA were the most isotopically distinct with low $\delta^{15} \mathrm{~N}$ and high $\delta^{13} \mathrm{C}$ values. Atlantic, Gulf of Mexico, Pacific, and Mediterranean loggerhead turtles had similar ratios with high $\delta^{15} \mathrm{~N}$ and low $\delta^{13} \mathrm{C}$ values. Considerable overlap is seen in the isotope ratios of juvenile loggerhead turtles in different ocean basins, with a relatively narrow range of $\delta^{13} \mathrm{C}$ values in all regions compared to $\delta^{15} \mathrm{~N}$ values. Fewer values were available for green turtles. Adult green turtles had similar $\delta^{15} \mathrm{~N}$ values for all ocean basins, whilst adults from the Pacific and Indian Ocean had low $\delta^{13} \mathrm{C}$ values in comparison to other ocean basins and the Atlantic had large ranges in isotope ratios. Isotope ratios were more distinct in juveniles, with

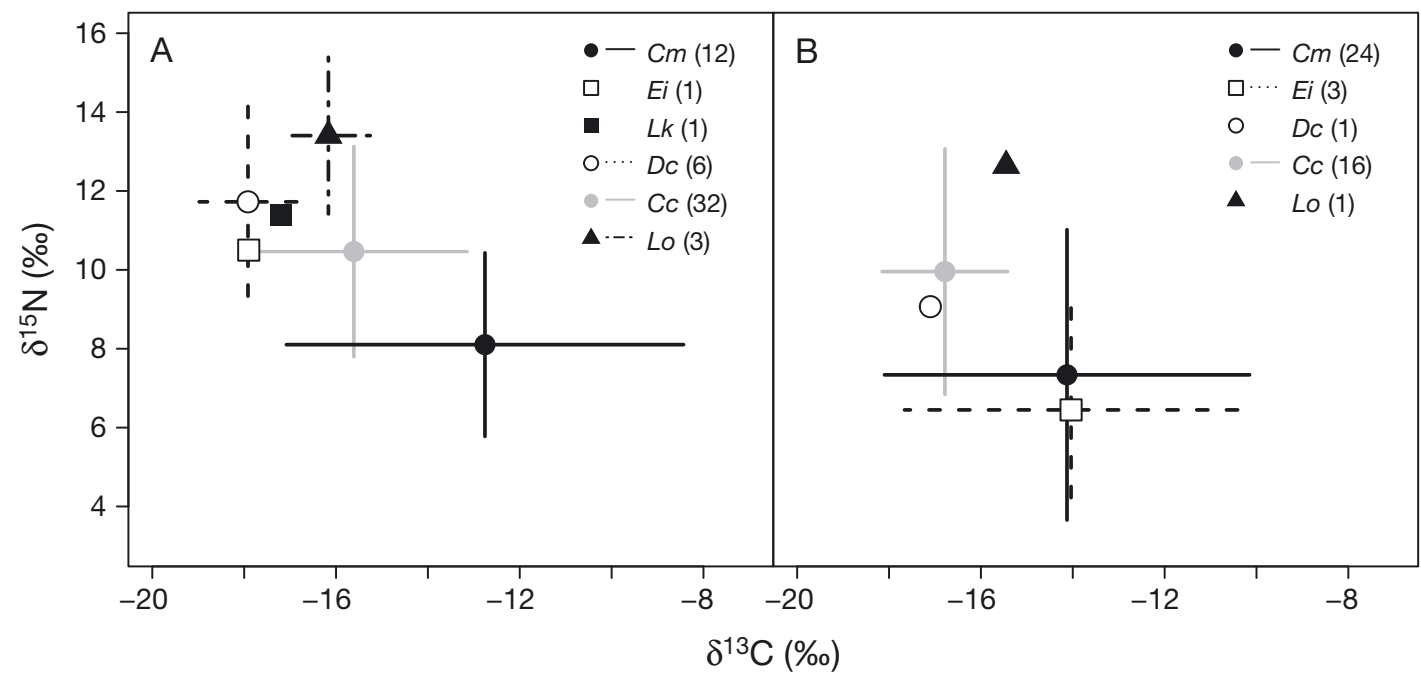

Fig. 3. Interspecific differences in stable isotope ratios in marine turtles. Mean of mean $\delta^{13} \mathrm{C}$ and $\delta^{15} \mathrm{~N}$ across studies of (A) adult and (B) non-adult marine turtles. Mean \pm SD shown where $n>1$. Number of studies contributing are shown in parentheses. Non-adults include juvenile, immature, and sub-adult individuals. For species abbreviations see Fig. 1 


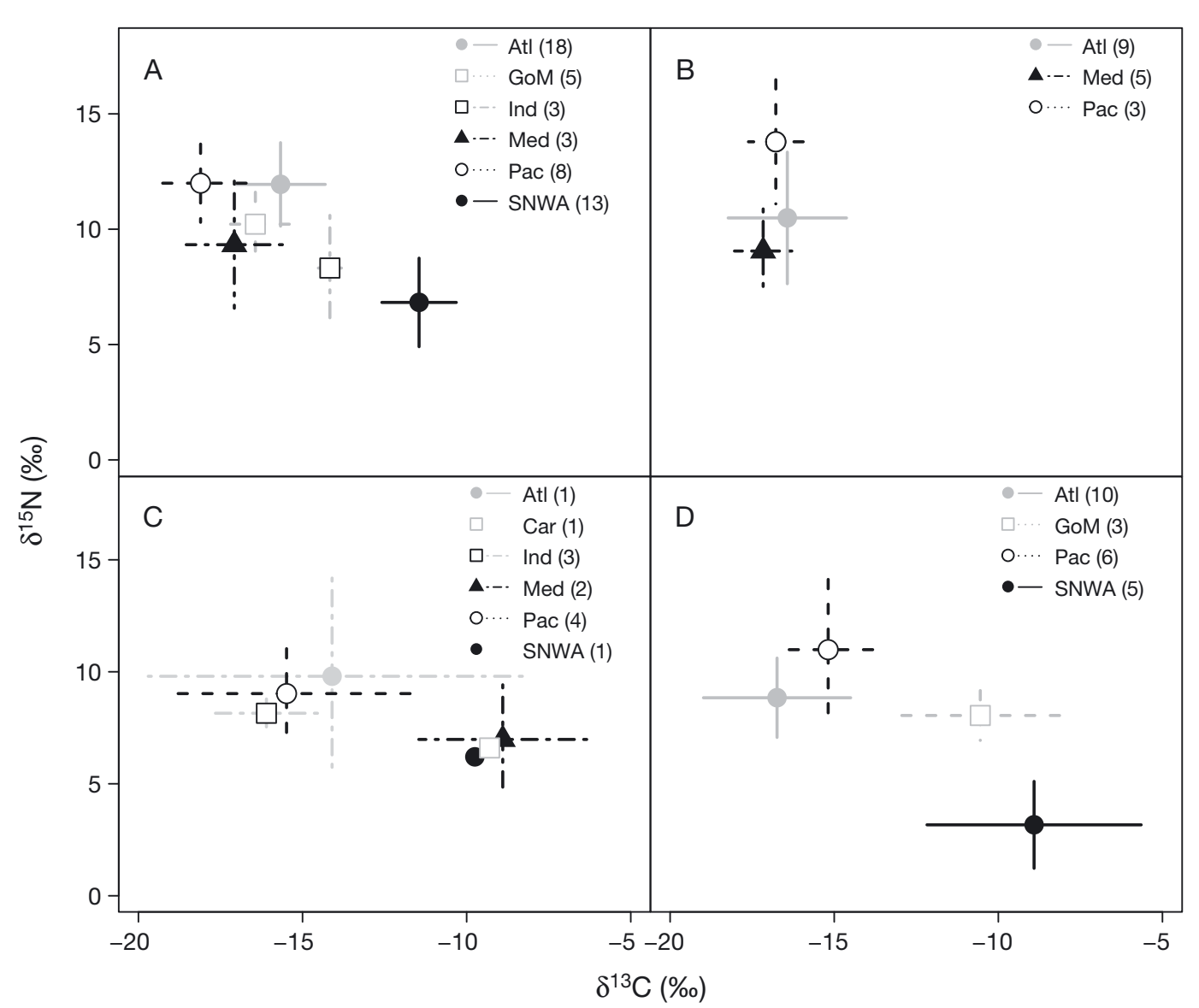

Fig. 4. Intraspecific variation of $\delta^{13} \mathrm{C}$ and $\delta^{15} \mathrm{~N}$ values for loggerhead turtle (A) adults, (B) non-adults, and green turtle (C) adults, and (D) non-adults. Mean \pm SD shown where $n>1$. Number of studies contributing are shown in parentheses. Nonadults include juvenile, immature, and sub-adult individuals. Atl: Atlantic Ocean; Car: Caribbean Sea; GoM: Gulf of Mexico; Ind: Indian Ocean; Med: Mediterranean Sea; Pac: Pacific Ocean; SNWA: subtropical Northwest Atlantic

those foraging in the SNWA showing low $\delta^{15} \mathrm{~N}$ and high $\delta^{13} \mathrm{C}$ values whilst Atlantic and Pacific foragers had low $\delta^{13} \mathrm{C}$ but high $\delta^{15} \mathrm{~N}$ values. Adult leatherback turtles had similar $\delta^{13} \mathrm{C}$ values for all ocean basins, whilst adults from the Pacific had relatively high $\delta^{15} \mathrm{~N}$ values.

Previously published ocean basin comparisons between Pacific and Atlantic leatherback (Wallace et al. 2006) and loggerhead turtles (Pajuelo et al. 2010) demonstrated those in the Pacific had higher $\delta^{15} \mathrm{~N}$ values. High $\delta^{13} \mathrm{C}$ and low $\delta^{15} \mathrm{~N}$ values have been reported in the SNWA and Caribbean Sea compared to the Gulf of Mexico and east coast USA for loggerhead and green turtles (Pajuelo et al. 2012b, Vander Zanden et al. 2013a, 2015, 2016, Tucker et al. 2014, Ceriani et al. 2017). Global variations in isotope ratios can be seen in previously created marine isoscapes (e.g. Somes et al. 2010, Magozzi et al. 2017, Bird et al. 2018), and we suggest intraspecies variations between ocean basin are due to dissimilarities in local and ocean basin nutrient cycling regimes that influ- ence isotope ratios at the base of the food web, which in turn influence the ratios of higher trophic level consumers. It is essential that when comparing isotope values from multiple regions, researchers quantify the baseline isotope ratios or obtain a proxy for the baseline ratios, for example from previous studies on lower trophic level species, amino acid $\delta^{15} \mathrm{~N}$ values, or isoscapes (maps of geospatial distribution of isotopes).

\subsubsection{Ontogenetic shifts}

The geographical location of marine turtle developmental stages and the movement between developmental areas are relatively unknown, as satellite telemetry of these life stages is limited (Godley et al. 2008). This is important information for conservation, as threats in these regions are less understood and in turn protection measures for this developmental life stage are limited (Hamann et al. 2010). 
Many studies have used isotopes to investigate ontogenetic shifts (Table 1). SIA has revealed that ontogenetic shifts are facultative not obligatory, depending on whether a habitat meets the demands of an individual (Hatase et al. 2006) and can be either over a year or over several years (e.g. Reich et al. 2007, Cardona et al. 2009, 2010, González Carman et al. 2014, López-Castro et al. 2014b, Ramirez et al. 2015, 2017 , Vélez-Rubio et al. 2016, Di Beneditto et al. 2017). Such analysis can also allow researchers to calculate the age and size at which an ontogenetic shift occurs (e.g. Snover et al. 2010, Avens et al. 2013, Ramirez et al. 2015, 2017, Howell et al. 2016, Turner Tomaszewicz et al. 2017a, 2018, Vélez-Rubio et al. 2018) and in turn estimate the duration of each life stage and the subsequent threats faced, which can be used to better understand and model population dynamics.

\subsubsection{Migratory connectivity}

To date, nesting beaches remain the main target for conservation action; however, as the terrestrial proportion of the life cycle of marine turtles is so brief, prioritising the conservation of important marine habitats and identifying the geospatial linkages within a population should be a priority. From nesting beaches, inaccessible foraging grounds and migratory connectivity can be identified using SIA (Table 1). To represent foraging grounds, tissues with slow turnover rates of months (e.g. epidermis) should be sampled (see Section 3.7 for recommendations on the tissue type to sample). By compiling all studies to date, we show the majority sampled foraging grounds (38\%, either by directed capture for research or using animals caught in fisheries), followed by nesting grounds $(35 \%)$, strandings $(26.5 \%)$, and/or mating grounds $(0.5 \%)$.

Quantifying the baseline isotope ratios in a region can be useful for interpreting marine turtle foraging and migratory behaviour. Several models have provided realistic predictions of global baseline isotope ratios (e.g. Tagliabue \& Bopp 2008, Somes et al. 2010, Schmittner \& Somes 2016, Magozzi et al. 2017) and a few isoscapes are available for the open ocean (e.g. Graham et al. 2010, McMahon et al. 2013). However, these show the geographical gradients of isotopes at very coarse resolutions. Recently, isoscapes have been developed for coastal and shelf areas (e.g. Vander Zanden et al. 2015, Trueman et al. 2017). SIA can be used in combination with satellite telemetry to identify foraging grounds with distinct isotope ratios and in turn assign individuals to putative foraging grounds. This has become common practice in marine turtle ecology, with the majority of studies that sampled nesting grounds proceeding to assign individuals to putative foraging grounds $(60 \%)$. This enables dispersion of adult females to be estimated with reasonable certainty. SIA can also be used to identify potential foraging grounds with distinct isotope ratios, even when these foraging grounds have not been previously identified via satellite telemetry. These can then be further investigated with targeted tracking of individuals to identify the location of the foraging ground associated with the distinct isotope ratios (e.g. Bradshaw et al. 2017).

Once the foraging grounds of a population have been identified, the relative importance of each foraging ground can be estimated by calculating the proportion of females supported by each area (e.g. Hatase et al. 2010, 2013, Reich et al. 2010, Zbinden et al. 2011, Eder et al. 2012, Cardona et al. 2014, Vander Zanden et al. 2014, Ceriani et al. 2015, 2017, Bradshaw et al. 2017, Price et al. 2017). Differences in the growth and reproductive output of each foraging ground can also be assessed and used as another method of determining the relative importance of a foraging ground (see Section 3.3). Long-term multiyear studies enable the contributions to annual nesting cohorts and recruitment to be estimated and therefore to identify foraging ground dynamics and in turn demographic trends of the population (e.g. Pajuelo et al. 2012a, Vander Zanden et al. 2014, Ceriani et al. 2015, 2017, Bradshaw et al. 2017, Price et al. 2017). This baseline information could then be used to target conservation efforts of more threatened and/or important foraging grounds.

In comparison to adult females, males are greatly underrepresented in stable isotope studies due to accessibility difficulties. Males should be prioritised for study, as the current dataset is not large enough to provide a solid conclusion on differences in isotope ratios between male and female marine turtles. Using SIA, adult males were suggested to forage in similar regions as females (Pajuelo et al. 2012b) and to forage on similar prey, as no differences were observed in the isotope ratios of male and female loggerhead (Thomson et al. 2012, Pajuelo et al. 2012a), green (Vander Zanden et al. 2013a, Prior et al. 2016), or olive ridley turtles (Peavey et al. 2017). Sex differences in isotope ratios were not observed in leatherback turtles when epidermis was sampled (Dodge et al. 2011, Wallace et al. 2014) but were observed within blood samples (whole blood and red blood cells; Dodge et al. 2011). Wallace et al. (2014) suggest the difference in findings between these studies is 
likely due to differences in incorporation rates among tissue types sampled, but could be due to betweensex foraging differences of different leatherback turtle populations. Although plasma has relatively quicker incorporation rates compared to epidermis, and therefore would explain differences in whole blood and epidermis isotope ratios, red blood cells have slow turnover rates that are similar to epidermis and thus represent similar time frames. Therefore, differences in foraging strategies may exist among leatherback turtle populations. This highlights the importance of selecting the correct tissue type for the question under investigation (see Section 3.7 for recommendations on the tissue type to sample).

\subsubsection{Foraging site fidelity}

To ascertain foraging site fidelity of an individual, the temporal consistency of their isotope ratios is commonly used (Table 1). SIA has been used to infer foraging site fidelity in marine mammals using whale baleen to create multiyear isotopic records to show shifts in foraging ecology and habitat use (e.g. Schell et al. 1989, Newsome et al. 2010). To determine temporal consistency in isotope ratios, marine turtle isotope studies have either combined skeletochronology and SIA, enabling prior diet and habitat to be reconstructed (see Section 3.6 for details on skeletochronology and SIA; e.g. Eder et al. 2012, LópezCastro et al. 2013, Wallace et al. 2014, Ferreira et al. 2018), or have sampled individuals across multiple years (e.g. Thomson et al. 2012, Tucker et al. 2014, Goodman Hall et al. 2015). However, there are limitations in using SIA for identifying foraging site fidelity, as other factors such as the influence of algal blooms or small scale nutrient cycling shifts on isotope ratios may occur rather than shifts in foraging location (e.g. Tucker et al. 2014). Therefore, stable isotopes alone are not entirely sufficient in some cases, and it is important to verify SIA with satellite telemetry or a third forensic marker (see Section 3.7 for recommendations on complementary techniques).

Marine turtle isotope studies have shown that postontogenetic juvenile loggerhead turtles and sexually mature females exhibit long-term site and diet fidelity (Hatase et al. 2002, 2013, Vander Zanden et al. 2010, 2016, Thomson et al. 2012, Tucker et al. 2014, Goodman Hall et al. 2015, Cardona et al. 2017). A study of male loggerhead turtles suggested the level of behavioural plasticity depends on the foraging ground used (Pajuelo et al. 2012b, 2016), showing SIA can be used to identify sex differences in life history strategies.
Eder et al. (2012) conducted SIA on the outer section of humeri from loggerhead turtles in Cape Verde and used skeletochronology to age the turtles. They found neritic loggerhead turtles in Cape Verde were older than adult oceanic foragers and suggested that females moved to more neritic regions, with increasing age suggesting foraging ground shifts can occur in later years. However, a later study on the same population by Cardona et al. (2017) analysed the isotope ratios from different layers of inert carapace and showed no isotopic differences. The latter study therefore suggested, instead of shifting habitat as reported by Eder et al. (2012), it was more likely that this population exhibits long-term site fidelity and that oceanic foragers had a shorter life expectancy (see Section 3.3 for more details on the carry-over effects of foraging grounds). This highlights how SIA results can be incorrectly interpreted and the importance of combining complementary techniques (see Section 3.7 for recommendations on complementary techniques).

Isotope-based studies examining the extent of site fidelity in adult green turtles found high foraging site fidelity (Shimada et al. 2014, Vander Zanden et al. 2013b, Bradshaw et al. 2017) whilst a study by Prior et al. (2016) demonstrates a common shift between foraging grounds. Prior et al. (2016) analysed two tissue types (epidermis and blood serum) which have different turnover rates (long and short, respectively) with isotope ratios of blood serum showing shortterm shifts in habitat use, whilst those showing foraging site fidelity used only one tissue type with slow turnover rates (scute or epidermis). This highlights that certain sampling methods have associated limitations on temporal detail, and this should be considered when interpreting results.

High site fidelity and individual specialisation could indicate limited adaptability to changes in foraging grounds and it is possible some individuals remain in sub-optimal foraging regions, which could have subsequent carry-over effects (see Section 3.3 for more details on the carry-over effects of foraging grounds).

\subsubsection{Foraging dichotomies}

Regardless of species, marine turtle hatchlings are considered omnivores that later switch to a more specialised diet. However, stable isotope studies have demonstrated the system is more complex. Nesting populations are not simply composed of females foraging in several similar foraging grounds with a specialised diet, but that in some cases a distinct foraging 
dichotomy occurs, for example with females foraging neritically or oceanically (Table 1). In general, adult loggerhead and green turtles were previously considered exclusive neritic foragers whilst leatherback turtles were thought of as oceanic foragers (Bjorndal 1997). Stable isotopes have revealed foraging dichotomy between oceanic and neritic foraging grounds for all three species (Hatase et al. 2002, 2006, Caut et al. 2008b, Watanabe et al. 2011, Eder et al. 2012, Cardona et al. 2017). Different foraging strategies will lead to exposure of different threats and environmental conditions and therefore conservation strategies must take this into consideration. Using SIA, different foraging strategies (oceanic vs. neritic) within a species have been highlighted in marine mammal research (e.g. Walker et al. 1999). Reich et al. (2010) proposed a nearshore-offshore foraging dichotomy for NWA loggerheads based on isotope ratios, however, this study did not use satellite telemetry whilst later studies using SIA and satellite telemetry suggested the isotopic difference is, in fact, more likely due to a latitudinal gradient (e.g. Ceriani et al. 2012, Pajuelo et al. 2012a). This highlights the importance of supporting SIA results with satellite telemetry (see Section 3.7 for recommendations on complementary techniques).

Foraging dichotomies represent dramatic life history differences within a population. For example, neritic loggerhead turtles are typically larger than their oceanic conspecifics, a difference in size that has been attributed to the nutritional benefits of neritic prey (Hatase et al. 2002, 2010, 2013, 2014, 2015, 2018, Watanabe et al. 2011, Eder et al. 2012, Cardona et al. 2017). Combing SIA and genetics, Watanabe et al. (2011) found nesting populations demonstrating foraging dichotomies were genetically homogeneous, suggesting that size-related foraging dichotomy may be due to phenotypic plasticity and that foraging habitats do not affect offspring morphology (Hatase et al. 2015, 2018). No size difference was observed between neritic and oceanic female green turtles suggesting the nutritional benefits of their main prey did not differ (Hatase et al. 2006). Difference in reproductive output has however been reported between individuals with different foraging strategies (see Section 3.3.3).

\subsection{Size, growth and reproductive output}

In addition to foraging and spatial ecology, marine turtle stable isotope studies have begun to elucidate the complexities of marine turtle reproductive ecology and other life history traits (Table 1). Carry-over effects, the influence of one activity (e.g. foraging) on another (e.g. breeding), will likely differ among foraging grounds and foraging strategies affecting fitness correlates (Harrison et al. 2011). As marine turtles generally show philopatry to foraging sites, carry-over effects could last longer than one remigration cycle.

\subsubsection{Juvenile size and growth}

Differences in turtle body size have been observed between foraging grounds in juvenile loggerhead turtles (Allen et al. 2013, Clusa et al. 2016) but not green turtles (Di Beneditto et al. 2017). Hatase et al. (2002) suggested that immature loggerhead turtles recruited to nutrient-rich benthic habitats will grow larger than those recruited to nutrient-low pelagic habitats, but will reach sexual maturity at a similar age (Hatase et al. 2010). Revelles et al. (2007a) found no difference in juvenile loggerhead turtle size between neritic and oceanic individuals; however, they also found the isotope ratios of prey items did not differ, suggesting all juveniles were foraging pelagically irrespective of water depth. Many studies investigate the direct relationship between size and $\delta^{15} \mathrm{~N}$ and/or $\delta^{13} \mathrm{C}$ values to infer the occurrence of ontogenetic shifts (e.g. Cardona et al. 2009, Goodman Hall et al. 2015, Vélez-Rubio et al. 2016, 2018, Burgett et al. 2018, Monzón-Argüello et al. 2018), diet (e.g. Wallace et al. 2009, Williams et al. 2014, Blasi et al. 2018, Ferreira et al. 2018), habitat differences (Bjorndal \& Bolten 2010), foraging site fidelity (e.g. Goodman Hall et al. 2015, Monzón-Argüello et al. 2018, Turner Tomaszewicz et al. 2018), age-atmaturity (e.g. Turner Tomaszewicz et al. 2018), and threats faced (e.g. Agusa et al. 2011, Clusa et al. 2016). These studies reported different relationships between juvenile size and $\delta^{15} \mathrm{~N}$ and/or $\delta^{13} \mathrm{C}$ values for loggerhead, green, and hawksbill turtles, suggesting difference in life history traits among populations. However, caution should be taken when interpreting isotope ratios in this regard, as incorporation rates and trophic discrimination factors (TDFs) can be influenced by body size and growth (see Section 3.5 for details on this limitation).

\subsubsection{Adult size and growth}

Morphological differences in female body size are a known factor affecting reproductive output (Bjorndal \& Carr 1989, Broderick et al. 2003) and therefore 
size differences between foraging strategies could influence reproductive fitness. Morphological differences in size have been seen between foraging grounds for females (Zbinden et al. 2011, Ceriani et al. 2014a, 2015, Vander Zanden et al. 2014, Price et al. 2017) but not males (although small samples sizes were reported for these; Pajuelo et al. 2012b, 2016). As with juveniles, the direct relationship between $\delta^{15} \mathrm{~N}$ and/or $\delta^{13} \mathrm{C}$ values and female size, regardless of foraging ground, is dependent on the species or population studied (Godley et al. 1998, Hatase et al. 2002, Burkholder et al. 2011, Eder et al. 2012, Thomson et al. 2012, Tucker et al. 2014, Wallace et al. 2014, Carpentier et al. 2015, Prior et al. 2016, Peavey et al. 2017). For sharks, $\delta^{13} \mathrm{C}$ values were not seen to differ with size for neritic or oceanic species; however, size did affect the isotope ratio of deep-sea sharks (at depths $>200 \mathrm{~m}$ ) suggesting their trophic ecology is size-structured (Bird et al. 2018).

\subsubsection{Reproductive output}

The allocation of resources to reproductive traits may differ between foraging grounds and may result in trade-offs between life history parameters. When female size is accounted for, foraging ground also affects loggerhead turtle clutch size. SIA and satellite telemetry have been used to identify foraging dichotomies within nesting populations and have been used to assign females to either neritic or oceanic foraging grounds (e.g. Hatase et al. 2002, 2006, Caut et al. 2008b, Watanabe et al. 2011, Eder et al. 2012, Cardona et al. 2017; see Section 3.2.7 for details on these studies). In turn, SIA studies have used this information to show females foraging in neritic regions had larger clutches and clutch volumes than their oceanic conspecifics (Eder et al. 2012, Hatase et al. 2013, 2015, 2018), whilst no difference was seen in egg size, nutritional components, hatchling size, or nest site selection between neritic and oceanic foragers, suggesting trade-offs between clutch size and egg quality do not occur (Hatase et al. 2014, 2015, 2018, Hatase \& Omuta 2018). In addition, studies investigating the isotopes of nesting females from populations only foraging in neritic regions found differences in clutch size were still evident among foraging grounds (Zbinden et al. 2011, Cardona et al. 2014, Ceriani et al. 2015, 2017) showing both foraging strategy and foraging location can cause carry-over effects.

Foraging ground did not affect loggerhead turtle hatchling production, as measured by the number of hatchlings that emerged from an individual nest, in populations exhibiting foraging dichotomy (Hatase et al. 2013, 2015, 2018) or between neritic foraging grounds in the Northwest Atlantic (NWA; Vander Zanden et al. 2014, Ceriani et al. 2015). However, a latter study of the NWA loggerhead turtles found there was a difference in hatchling production between foraging grounds. This inconsistency was not discussed in Ceriani et al. (2015); however, Ceriani et al. (2017) isotopically assigned females to more foraging regions than previous studies and used a continuous-surface approach that, they stated, was an improvement on previous assignment models allowing for the inclusion of all sampled individuals. This highlights the importance of identifying all foraging grounds utilised by a population and how analytical developments can improve the interpretation of isotope ratios.

Remigration interval (the number of years between breeding events) is dependent on the quality and quantity of resources at the foraging ground, as individuals require energy reserves for migration, vitellogenesis, and nesting (e.g. Saba et al. 2007). Foraging ground has been seen to affect the remigration interval of loggerhead turtles (Vander Zanden et al. 2014, Ceriani et al. 2015); in particular, those isotopically assigned to neritic foraging regions had shorter remigration intervals than those foraging in oceanic regions, which could lead to higher reproductive output (Hatase et al. 2013). This was also observed for leatherback turtles (Caut et al. 2008b), whilst Hetherington et al. (2018) suggested oceanographic conditions (North Atlantic Oscillation) may influence leatherback turtle nesting parameters with low North Atlantic Oscillation values linked with low $\delta^{15} \mathrm{~N}$ values, longer remigration intervals, and lower clutch frequency.

Female loggerhead turtles assigned to neritic foraging grounds, in comparison to their oceanic conspecifics, had higher clutch frequency (number of clutches in a season), breeding frequency (number of nesting seasons) and in turn cumulative reproductive output with more emergent hatchlings (Hatase et al. 2013). Clutch frequency varied more for neritic foragers than oceanic foragers and was attributed to shifts in prey availability (Hatase et al. 2013). Individuals from neritic-only foraging grounds were interpreted as having slight differences in arrival date (Vander Zanden et al. 2014), which can affect the temperature of incubation and in turn the sex ratio (Wibbels 2003). No differences were seen for individuals isotopically assigned to foraging grounds in the number of clutches laid (Vander Zanden et al. 2014), duration of the nesting season (Vander Zanden et al. 
2014), breeding lifespan (period from first to last nesting season) (Hatase et al. 2013), age at sexual maturity (Hatase et al. 2010), incubation duration (Hatase et al. 2015, 2018), survival (Hatase et al. 2013), or hatchling righting response (Hatase et al. 2018).

\subsection{Applications of SIA for management and conservation}

In addition to the conservation insights afforded by enhancing the understanding of ecology, stable isotope studies have been used to identify and better contextualise threats faced by marine turtles. One of the earliest applications of SIA was for wildlife forensics to determine the origin of 'tortoise-shell' for the management of the illegal trade of turtle products (Moncada et al. 1997). SIA has been used successfully to aid the policing of African elephant Loxodonta africana ivory (Vogel et al. 1990) and could be used for reptile populations, e.g. crocodile lizards Shinisaurus crocodilurus (van Schingen et al. 2016). Moncada et al. (1997) analysed $\delta^{13} \mathrm{C}$ and $\delta^{15} \mathrm{~N}$ values and showed no distinct difference in the isotope ratio of ranched versus wild hawksbill turtles. Within this review we have highlighted the difficulty of distinguishing marine turtle species based on $\delta^{13} \mathrm{C}$ and $\delta^{15} \mathrm{~N}$ values (see Section 3.2.2); therefore, analysis of additional elements or alternative forensic markers is required for wildlife forensics to successfully identify the origin of marine turtle products.

As a result of foraging site fidelity, SIA of inert tissue has the potential to provide pre- and post-disaster information that is often unavailable and has shown individuals appear to remain in foraging grounds even after devastating anthropogenic activities. For example, after the Deepwater Horizon disaster in 2010, turtles in the Gulf of Mexico continued to forage in oil- and chemical dispersant-affected areas (Vander Zanden et al. 2016, Reich et al. 2017), resulting in the potential incorporation of pollutants and a slowing of the growth of the population (Reich et al. 2017).

The incorporation of contaminants offers a possible practical application in the use of toxicological proxies as additional forensic markers to help further separate foraging regions in marine mammal (e.g. Born et al. 2003, Krahn et al. 2008) and shark studies (Shiffman et al. 2012) and could be utilised further in future marine turtle isotope research. SIA has been used in marine turtle ecotoxicology studies to show the presence of pollutants in marine turtles, including the increase of persistent organic pollutants in green turtles fed fish and cephalopods by divers (Monzón-Argüello et al. 2018). SIA has also been used to show the effect of provisioning for ecotourism in elasmobranchs (e.g. Maljkovi \& Côté 2011) and the impact of consuming fishery discards on fish (e.g. Boyle et al. 2012) and seabirds (e.g. Forero \& Hobson 2003, Bugoni et al. 2010). SIA has helped reveal highly elevated mercury levels in green turtles foraging close to industrial activities despite foraging on the same prey as individuals foraging in non-industrial areas (Bezerra et al. 2015). Bioaccumulation of arsenic and arsenic compounds was observed in green and hawksbill turtles with the latter more carnivorous species, as demonstrated by SIA, exhibiting heavier loading (Agusa et al. 2011). The presence of Fukushima-derived radiocesium in olive ridley turtles (Madigan et al. 2017), and low maternal transfer of lead (attributed to non-anthropogenic sources) in nesting olive ridley females has been assessed using SIA (Páez-Osuna et al. 2010). Biomagnification of pollutants up through trophic levels has also been assessed using SIA in marine mammals and seabirds (e.g. Forero \& Hobson 2003, Tomy et al. 2004, Newsome et al. 2010).

Isotope studies have enabled interactions with fisheries to be identified, including the consumption of fishery discards by green (Turner Tomaszewicz et al. 2018) and olive ridley turtles (Petitet \& Bugoni 2017), potential ingestion by loggerhead turtles of fish and squid from baited long-line hooks, which poses a potential bycatch threat (Revelles et al. 2007a, Blasi et al. 2018), and juvenile loggerhead turtles foraging food commonly bycaught or purposefully caught, which could increase competitive interactions (Wallace et al. 2009). Previous SIA work has found the size and genetic stock of turtles bycaught is based on fishing region, not fishing gear, which can help target conservation (Clusa et al. 2016). Isotope ratios revealed olive ridley turtles foraged in neritic and oceanic grounds, showing they can encounter both longline and trawl fisheries, which is of concern (Petitet \& Bugoni 2017); and that loggerhead turtles caught in California drift gillnets are likely those that normally forage in the central North Pacific, which are incidentally caught in the Hawaii-based longline fishery (Allen et al. 2013).

Stable isotope studies have also shown predation of marine turtle hatchlings by black rats Rattus rattus during the offseason for seabird nesting (Caut et al. 2008a) and the importance of turtle eggs as a nutrient input to the beach ecosystem, aiding in dune and beach stabilisation (Hannan et al. 2007, Le Gouvello et al. 2017). 


\subsection{Limitations of SIA}

With technological and statistical advancements, the strength of SIA is ever-increasing. However, there are still many limitations to this tool, which should be considered in future studies and understood when reading the current SIA literature. For detailed reviews on the limitations of SIA in ecology see Martínez del Rio et al. (2009) and Wolf et al. (2009). Here we summarize the major limitations and caveats of using SIA in marine turtle ecology.

Temporal variations in the stable isotope ratios at the base of the food chain can occur, for example seasonal fluctuations of zooplankton isotope ratios (Hannides et al. 2009). This is likely due to temporal changes in the physicochemical and biological composition of the primary producers (Ramos \& GonzálezSolís 2012). This variability will be transferred up the food chain, putting into question the seasonal stability of stable isotopes and isoscapes which are relied on to trace predator movements (Graham et al. 2010, Ramos \& González-Solís 2012). For example, seasonal differences observed by Tucker et al. (2014) for loggerhead turtles in the Gulf of Mexico were due to baseline changes in isotope ratios, which were exhibited up the food chain, rather than seasonal habitat shifts of the turtles. This can limit the use of SIA in assignment studies and highlights the importance of using complementary satellite tracking to confirm the foraging site fidelity of a population.

Newsome et al. (2010) describe in detail why isotope ratios may shift during fasting and periods of nutritional stress in marine mammals and may explain why isotope ratios of marine turtles could shift across a nesting season due to fasting, migratory foraging, inter-nesting foraging, or a consequence of egg formation (e.g. Hatase et al. 2006, Caut et al. 2008b, Zbinden et al. 2011, Petitet \& Bugoni 2017). We therefore recommend samples be taken from breeding individuals as early in the season as possible to best represent the foraging ground.

The time frame represented by each tissue type is dependent on the metabolic turnover rate of that tissue (Reich et al. 2008). Isotopic turnover rates can vary with body size, growth rate, diet quality, and protein turnover (for details, see review by Wolf et al. 2009). Known turnover rates of tissues are important but lacking in large marine taxa, such as marine turtles, seabirds (Forero \& Hobson 2003), marine mammals (Newsome et al. 2010), and elasmobranchs (Shiffman et al. 2012) due to the limited ability to perform diet-switching experiments. Therefore the time frame that tissue-types represent is not well known despite being required to accurately interpret SIA results and should be carefully considered when designing future ecological studies (Ramos \& GonzálezSolís 2012).

Inherent variation of stable isotopes (isotope differences between consumers due to differences in their physiology, not diet) are often overlooked in marine turtle SIA studies, and instead the variation in isotope ratios between individuals is related to differences in diet or habitat. To estimate dietary or habitat effects on the stable isotope composition of a population with greater confidence, the amount of inherent variation within the population needs to be estimated; but this information is sparse in ecology studies (Barnes et al. 2008), and the marine turtle literature is no exception. Vander Zanden et al. (2012) found that a small portion of the isotopic variation measured in a wild green turtle population was due to inherent variation, whilst the majority of variation resulted from diet and/or habitat differences. Similar values of inherent variation were reported for juvenile green turtles by Seminoff et al. (2006a), whilst Seminoff et al. (2009) found juvenile leatherbacks had larger inherent variation (for comparison between these studies, see Vander Zanden et al. 2012). As inherent variation can differ with species, life stage, and tissue (Barnes et al. 2008, Vander Zanden et al. 2012), additional studies are required for marine turtles, and Barnes et al. (2008) suggests inherent variation should be quantified on a case-by-case basis.

Trophic discrimination factors (TDFs) are the difference between predator and prey isotope ratios (represented as $\Delta=\delta_{\text {tissue }}-\delta_{\text {diet }}$ ) and are used in SIA literature to infer relative trophic positions and for dietary reconstructions. However, a clear understanding of TDFs is critical to prevent the incorrect interpretation of isotope ratios and incorrect outputs for mixing models (Post 2002, Caut et al. 2009, Martínez del Rio et al. 2009, Wolf et al. 2009).

Many studies use generalised diet-tissue discrimination factors such as $3-4 \%$ for nitrogen and 0-1\% for carbon (Post 2002), as species-specific TDFs are limited (Caut et al. 2009). This is because they require studies of captive individuals fed on a consistent diet for sufficient time, which is difficult especially for large marine vertebrates such as marine turtles (Turner Tomaszewicz et al. 2017b). There are only a few TDFs available for marine mammals (Newsome et al. 2010), and elasmobranchs (Shiffman et al. 2012). See Newsome et al. (2010) for review of TDFs in marine mammals. TDFs are limited for marine turtles but have been estimated for several tissues types, life stages, and 
species, including juvenile and adult green turtles (Seminoff et al. 2006a, Vander Zanden et al. 2012, Turner Tomaszewicz et al. 2017b), hatchling and juvenile loggerhead turtles (Reich et al. 2008) and juvenile leatherback turtles (Seminoff et al. 2009); however, these are often based on small sample sizes. Differences were observed between the TDFs calculated for juvenile green turtles by Seminoff et al. (2006a) compared to those calculated by Vander Zanden et al. (2012) and Turner Tomaszewicz et al. (2017b). This difference was attributed to differences in diet, growth rates, and lipid extraction and highlights the sensitivity of TDFs. The majority of these study animals were fed pelleted diets, whilst future experimental studies should ideally use the same food sources the consumers would encounter in the wild (Healy et al. 2018, Caut et al. 2009). These species-specific TDFs have been used by other marine turtle studies even when sampling different populations, life stages, or tissue (e.g. Burgett et al. 2018, Gillis et al. 2018, Monzón-Argüello et al. 2018).

When discrimination factors cannot be measured experimentally, Caut et al. (2009) propose a way of estimating the TDF of a consumer (the Diet-Dependent Discrimination Factor method); however, this only provides a mean TDF that can then be included in isotope mixing models (see Section 3.6 for details on isotope mixing models). A new analytical approach to estimate TDFs has been developed, the $\mathrm{R}$ package SIDER (Healy et al. 2018), which calculates the TDF of a consumer based on their ecology and phylogenetic relatedness. The estimated TDF and the associated uncertainty can then be included in mixing models. However, this $\mathrm{R}$ package is not yet applicable to reptiles.

There are also new Bayesian techniques to estimate the trophic position of a consumer, for example, the R package tRophicPosition (Quezada-Romegialli et al. 2018). This approach estimates the trophic position of a consumer at a population level using the consumer and baseline stable isotope ratios, whilst taking into account inherent variation within the population and sampling errors for TDFs and baseline and consumer isotope ratios (Quezada-Romegialli et al. 2018). One limitation of this method is that TDFs are incorporated into the model as raw data and Quezada-Romegialli et al. (2018) suggest the selection of a representative TDF is critical. Additionally, there are empirical ways to estimate trophic position, for example using compound-specific SIA (CSIA) of amino acids, which are discussed in Section 3.6 .
Many studies suggest TDFs are an important area for future methodological work, however, we recommend treating the concept of TDFs with caution, as the processes that influence TDFs are not fully understood and they are likely highly dynamic, with incorporation rates of intrinsic markers into tissues differing not only with species but with sex, life stage, isotope analysed, isotopic routing, growth rates, tissue sampled, health, diet isotopic composition, and diet quality (e.g. Seminoff et al. 2006a, Reich et al. 2008, Vander Zanden et al. 2012, Turner Tomaszewicz et al. 2017b).

Martínez del Rio et al. (2009) and Wolf et al. (2009) highlight that there are far more observational field studies applying SIA than there are experimental studies aiming to understand the mechanisms behind stable isotopes and SIA, and suggest field data be accompanied by laboratory experiments. We support this recommendation and suggest the important limitations overviewed here should be considered during the design of future marine turtle studies and should be understood when reading SIA literature. Despite these limitations, SIA is undoubtedly an invaluable tool for marine turtle ecology.

\subsection{Additional analytical approaches}

Throughout the SIA literature, complementary techniques are often used to offer further insights about marine turtle ecology, including satellite telemetry, genetics, and stomach content analysis (as discussed in Section 1.1). Other tools used in SIA research include skeletochronology, CSIA, and mixing models. As these will likely become more common in the SIA literature we offer a brief overview of these techniques.

Many marine turtle SIA studies sample mineralised tissues such as scutes and humeri, as the isotope ratios of these chemically inert accretionary tissues do not change after formation (Snover et al. 2010). Skeletochronology specifically relates to analysing skeletal growth increments, which in marine turtle research is usually sampled from humeri. SIA of inert tissues enables a time-series of the prior diet and habitat to be reconstructed from different layers of the accretionary tissue, showing either seasonal or inter-annual changes. This technique is often used to infer life history patterns, for example the occurrence of ontogenetic shifts (e.g. Ramirez et al. 2017, Turner Tomaszewicz et al. 2017a), or to track movements (e.g. López-Castro et al. 2013, Vander Zanden et al. 2015). Marine mammal isotope studies have analysed 
accretionary tissues such as teeth to show dietary shifts, differences in maternal strategies, as well as ontogenetic shifts (Newsome et al. 2009, 2010). One limitation of this technique is understanding the species-specific growth rates and turnover rates and therefore the time frame each tissue layer represents, and this is recommended for future experimental work (Pajuelo et al. 2016). The periodicity of bone growth layers have, however, been validated for several marine turtle species (Snover et al. 2007, 2010). Another limitation of sampling scute is that unlike bone, scute tissue only represents a short time-series of 0.8 to 2 years (Vander Zanden et al. 2013b). Turner Tomaszewicz et al. (2017a) highlight the likely time delay between prey consumption and the assimilation into inert accretionary tissues, which may prevent a detailed estimation of the ontogenetic shift, especially in the most recent tissue layers. In addition, samples from humeri can only be obtained from dead turtles during necropsies, whilst scute samples can be obtained non-invasively depending on the depth of sample required.

CSIA can provide additional and in many cases more detailed information to bulk tissue SIA, helping to minimize assumptions related to the interpretation of bulk tissue isotope ratios (see review by Evershed et al. 2007). Stable isotopes of specific organic molecules, e.g. fatty acids and amino acids, have only been analysed in a few marine turtle studies (e.g. Belicka et al. 2012, Cardona et al. 2015) but are likely to be used more frequently in the future.

Fatty acid fingerprinting and amino acid analysis can be important techniques in diet studies aiming to trace the source of organic matter in food webs and the relative abundance of prey items within a diet (Belicka et al. 2012). In some cases, SIA alone cannot differentiate between primary sources of organic matter (seagrass, epiphytes, macroalgae) and therefore might over- or under-emphasise their importance within diets (Jaschinski et al. 2008, Crawley et al. 2009, Larsen et al. 2012). Taxon-specific fatty acids are produced by phytoplankton, microzooplankton, and bacteria which are deposited into consumer adipose tissue with minimal modification and are therefore reflected within their consumers (Iverson et al. 2004, Budge et al. 2006). This enables fatty acid fingerprinting to estimate the source of organic matter at the base of a consumer's food chain (Ramos \& González-Solís 2012).

Fatty acid fingerprinting in combination with SIA has been used to estimate the contribution of primary producers to green and loggerhead turtle diets in Shark Bay, Australia (Belicka et al. 2012). However, that study suggested large sample sizes are required to separate these primary producers further. Belicka et al. (2012) also suggest fatty acid fingerprinting should be used with caution for green turtles, as hindgut bacterial fermentation could cause considerable modifications of fatty acids prior to deposition in lipid reserves (Seaborn et al. 2005). Higher trophic prey items can also be distinguished within marine turtle diets, for example the contribution of sardines and anchovies to marine turtle diet (e.g. Cardona et al. 2015). Fatty acid isotopes are considered more specific to the dietary source compared to bulk stable isotopes; whilst physiology could influence fatty acid isotope ratios of consumers. This was not considered to be the case for green and loggerhead turtles (Cardona et al. 2015). De Troch et al. (2012) highlight the importance of considering bioconversion of fatty acids when using them as biomarkers, as it is possible they undergo degradation and transformation through the food chain. Fatty acids also only make up a small proportion of the total organic carbon, whilst amino acids account for a large proportion of organic carbon and nitrogen, and therefore amino acid analysis is considered more representative of the diet as a whole (Hedges et al. 2001).

Essential amino acids (EAAs) produced at the base of the food chain have distinct isotope ratios (i.e. $\left.\delta^{13} \mathrm{C}_{\mathrm{EAA}}\right)$ and, due to little to no isotopic fractionation up the foodchain, can be used as intrinsic markers throughout the food chain to high trophic consumers (O'Brien et al. 2002, Larsen et al. 2009, 2012, 2013). In addition, bulk $\delta^{13} \mathrm{C}$ values at the base of the food chain can be influenced by variable environmental conditions (affecting growth rates and cell surface area) whilst $\delta^{13} \mathrm{C}_{\mathrm{EAA}}$ does not appear to be affected by environmental conditions (Larsen et al. 2013). However, as with fatty acids, hindgut fermentation performed by hindgut microflora in consumers, e.g. green turtles, might influence $\delta^{13} \mathrm{C}_{\mathrm{EAA}}$. EAAs have been used to explore the influence of marine turtle gut microflora on $\delta^{13} \mathrm{C}_{\mathrm{EAA}}$. By analysing $\delta^{13} \mathrm{C}_{\mathrm{EAA}}$ in herbivorous green turtle tissue, Arthur et al. (2014) found that individuals receive a large contribution of EAAs from a bacterial source, whilst EAAs of carnivorous green, loggerhead, and olive ridley turtles were from microalgae sources in oceanic food webs. EAAs could therefore be used to differentiate between herbivores and carnivores; however, it does not differentiate whether the bacterial source of $\delta^{13} \mathrm{C}_{\mathrm{EAA}}$ is from gut microflora or epiphytes in the food. Further analysis (linear discriminant analysis) was required to show the $\delta^{13} C_{\text {EAA }}$ indeed stemmed from gut microflora (Arthur et al. 2014). 
A limitation of SIA is the inability to decipher whether differences in bulk $\delta^{15} \mathrm{~N}$ values are due to baseline isotope shifts or the influence of the trophic position of the consumer. CSIA of amino acids can determine if differences in bulk $\delta^{15} \mathrm{~N}$ values are due to differences in trophic amino acids (e.g. glutamic acid and alanine), which reflect trophic level, or source amino acids (e.g. phenylalanine and lysine), which reflect isotope composition of the primary producers at the base of the food chain (McClelland \& Montoya 2002). This enables trophic position to be estimated without sampling prey items (Seminoff et al. 2012) and has been used to show that differences in bulk $\delta^{15} \mathrm{~N}$ values were due to baseline shifts, instead of differences in trophic position, for leatherback (Seminoff et al. 2012, Hetherington et al. 2018), green (Vander Zanden et al. 2013a), and olive ridley turtles (Peavey et al. 2017), which could have been misinterpreted using bulk SIA alone.

Amino acid analysis has been recommended for use in future marine mammal research to help disentangle spatial and trophic differences in isotope ratios; however, Newsome et al. (2010) state that controlled feeding studies are required to confirm the distinction between source and trophic amino acids. Peavey et al. (2017) recommend that amino acid-specific incorporation rates and trophic discrimination factors need to be better understood for different marine turtle species and tissue types. Larsen et al. (2012) highlight two limitations of amino acid analysis. Firstly, primary producers could contribute to the diet of a consumer and not be reflected in the amino acids, as amino acids are not equivalent to the entire diet, and secondly, isotopic differences in amino acids between the diet and a consumer has been seen in some consumers, especially those with protein-poor diets.

CSIA of fatty acids and amino acids is complicated by the complex food chains used by marine turtles, especially carnivorous species, the diet of which will likely be based on a range of primary producers (Arthur et al. 2014). Arthur et al. (2014) discuss the potential power of analysing the isotopes of specific compounds compared to bulk tissue analysis, but highlight the need for controlled studies to validate their interpretation, which is also recommended by Larsen et al. (2012). As with any analytical tool, CSIA has considerable cost in terms of analysis time and expense, which can limit sample size (e.g. Vander Zanden et al. 2013a) and has to be considered in study design.

In marine turtle research, isotope mixing models are used to estimate the proportional contribution of dietary items to the diet of a consumer (e.g. McClellan et al. 2010, Burgett et al. 2018, Gillis et al. 2018, Monzón-Argüello et al. 2018). Within the field of isotope ecology, common analytical tools used are isotope mixing models, such as linear mixing models like IsoSource (Phillips \& Gregg 2003), or Bayesian mixing models like SIAR (Stable Isotope Analysis in

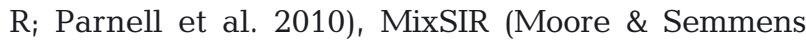
2008), and MixSIAR (Stock \& Semmens 2016). IsoSource calculates a range of possible dietary contributions that could result in the consumer isotope ratio and is a very common tool used in SIA due to its ease of use, public availability, and the limited input data required; however, model outputs are often misinterpreted (Layman et al. 2012). Bayesian mixing models suggest the most likely proportional contribution of sources to consumers as these use additional a priori knowledge (e.g. proportional contributions of sources and potential variability in all input parameters; Layman et al. 2012). Although more advanced than IsoSource, Bayesian mixing models have high data requirements and are still sensitive to the quality of input values (for further details on isotope mixing models and their limitations, see review by Layman et al. 2012).

There are numerous conceptual and methodological issues surrounding the use of SIA in diet reconstruction, especially using mixing models (Martínez del Rio et al. 2009, Wolf et al. 2009). To build a mixing model, TDFs and incorporation rates are required for the specific tissue, life stage, and species being analysed. As discussed in Section 3.5, these are limited for marine turtles. For best results, all prey items must be included and sampled on the same time frame as the consumer tissue is synthesised (Layman et al. 2012). Sampson et al. (2017) were unable to successfully run a MixSIAR for green turtles due to the exclusion of important prey items that were not considered potential prey from previous oesophageal lavage sampling, and Williams et al. (2014) felt they were unable to sample all prey items, preventing them running mixing models.

Dodge et al. (2011) also recommend locally sampled prey items to be used in preference to published isotope ratios, as inconsistencies in the isotope ratios of prey occur. Burgett et al. (2018) highlight the importance of including prey isotope ratios that are area-specific to prevent dramatically under- or overestimating prey proportions or trophic position. Large variation in baseline isotope ratios can make the results harder to interpret as seen for green turtles by Vélez-Rubio et al. (2016), and Layman et al. (2012) suggest that, as temporal and spatial variability of 
source isotope ratios increase, the sampling effort must increase to represent this detail. Lack of distinct differences in isotope ratios between prey items especially within similar food groups (e.g. Shimada et al. 2014) limits the ability of mixing models to estimate the diet of a consumer (Layman et al. 2012). Bias in the detection of animal matter versus plant material might occur, as animal matter is proteinbased and is incorporated directly into the tissue of the turtle (Cardona et al. 2009). Determining the proportion of prey in the diet of a population can also change depending on the mixing models used (Goodman Hall et al. 2015).

\subsection{Key recommendations}

This review reveals that several common recommendations have been made throughout the SIA literature, including standardised protocols for tissue collection and preservation, the use of an additional forensic marker or complementary techniques to provide greater power of inference, and compiling the isotope ratios of marine turtles at a global scale to facilitate meta-analytical approaches (Table 2). This review and inventory also leads us to emphasise the variation in methodological approaches used (for details on the methodology used by each study, see the data archive at https://doi.org/10.1594/PANGAEA. 892683). For global comparisons to be made, standardised protocols are needed; however, there are scientific reasons for choosing particular tissues and techniques for specific studies, and we understand these should be the primary methodological drivers.

Isotope ratios of marine turtle tissue change with decomposition (Payo-Payo et al. 2013), therefore tissues must be preserved. However, the preservation of samples, including blood anticoagulants, has been shown to significantly affect isotope ratios (Barrow et al. 2008, Lemons et al. 2012, Kaufman et al. 2014, Carpena-Catoira et al. 2016). We recommend a standardised preservation technique should be implemented for each tissue type in future research, although we understand logistical reasons could restrict what techniques are used. This was also recommended by Newsome et al. (2010) for SIA in marine mammals.

Carpena-Catoira et al. (2016) recommend the storage of epidermis in dimethyl sulfoxide (DMSO) buffer when storage in liquid nitrogen is not possible; however, these authors only compare these two preservation methods. Barrow et al. (2008) found DMSO affects epidermis isotope ratios whilst ethanol does not. Storage of epidermis in ethanol was also the most common technique $(44 \%$ of studies sampling epidermis) and therefore we recommend this preser-

Table 2. Key recommendations for future marine turtle stable isotope studies. SIA: stable isotope analysis; CSIA: compoundspecific SIA

\begin{tabular}{|ll|}
\hline Category & Recommendation \\
\hline General & Target under-studied species \\
& Cover a larger geographical range \\
& Target males \\
& Collaborate for meta-analytical approaches \\
Tissue preservation & Use a standardised technique, e.g. store epidermis in $70 \%$ ethanol and freeze yolk \\
& samples \\
Lipid extraction & Use a standardised technique for each tissue type \\
Tissue type & Only collect multiple tissue types when comparing short- and long-term foraging \\
& Use epidermal tissue for long-term information \\
& Use unhatched egg yolk as a proxy for unobserved nesting females \\
Tissue type conversion equations & Conduct more research on tissue turnover rates \\
Trophic discrimination factors & Use conversion equations with caution \\
Proportion of prey in diet & Conduct more research on discrimination factors \\
& Use a standardised isotope mixing model \\
Geographical assignment & Use locally sampled prey \\
& Know all foraging grounds of the population \\
& Determine foraging site fidelity \\
& Collect samples from as early in the nesting season as possible \\
Study duration & Use a third forensic marker for greater power of inference \\
& Combine SIA with complementary techniques, e.g. satellite telemetry and CSIA \\
& Conduct multi-year studies so shifts in population dynamics can be documented and \\
& pre- and post-disaster information to be obtained \\
\hline
\end{tabular}


vation technique. Kaufman et al. (2014) recommend egg contents be frozen and only stored in ethanol if a freezer is unavailable. We support this recommendation, and freezing of egg contents was the most common technique $(89 \%$ of studies sampling egg contents). Based on the most common techniques used we also recommend epibionts and tendons be stored in ethanol, inert tissues such as scute and humeri that do not decay to be air-dried, and freezing of muscle, blood, and liver. In addition, Lemons et al. (2012) recommend sodium heparin as the best blood anticoagulant when immediate centrifugation is not possible.

Despite using the same tissue type, there was variation in whether lipid extraction was performed or correction factors applied. In some cases, lipid extraction was found to influence isotopes and these differences were biologically relevant and therefore caution must be exercised (Kaufman et al. 2014, Carpentier et al. 2015, Medeiros et al. 2015, Bergamo et al. 2016). Many studies use the recommendation that samples with $\mathrm{C}: \mathrm{N}>3.5$ should undergo lipid extraction (Post et al. 2007); however, Bergamo et al. (2016) showed the $\mathrm{C}: \mathrm{N}$ ratio might not reliably predict the lipid content of marine turtle tissue samples. Newsome et al. (2010) recommend that all studies should report the mean C:N ratio and associated error of tissues undergoing SIA, which we support. We agree with the recommendation by Carpentier et al. (2015) that ideally samples would be analysed twice, pre- and post-extraction, but it is appreciated that this adds to time and cost of analysis, as highlighted by Kaufman et al. (2014) and Bergamo et al. (2016). For diet studies sampling prey items, we support the recommendation by Newsome et al. (2010) that prey items, especially lipid-rich prey, should be analysed pre- and post-extraction. Numerous chemical treatments were utilised in the extensive shark SIA dataset compiled by Bird et al. (2018) and the importance of tissue preservation, preparation, and lipid extraction methods have been highlighted as key analytical considerations in marine mammal (Newsome et al. 2010) and elasmobranch research (Shiffman et al. 2012), supporting the conclusion that the use of standardised protocols is important in all marine SIA applications.

Numerous tissue types are used in the field of marine turtle SIA (see Section 3.1) as well as other marine taxa including marine mammals (Newsome et al. 2010). As the tissue type used represents different time frames of dietary information (Reich et al. 2008), we recommend multiple tissue types only to be collected when comparing short and long-term foraging (e.g. Petitet \& Bugoni 2017). The use of multiple tissues with different turnover rates has shown onto- genetic shifts in elasmobranchs (Shiffman et al. 2012). Newsome et al. (2010) recommend that for marine mammal SIA, tissues selected for analysis should have long integration times and relatively slow turnover rates (e.g. epidermis) to prevent short-term diet affecting the overall isotope ratios. We also recommend that for long-term information, flipper epidermal tissue, which has a turnover of months (Reich et al. 2008), is best and would allow comparisons between hatchlings, juveniles, and adults. Hatchling and egg tissue is derived from the mother and represents her isotope ratios (Frankel et al. 2012, Kaufman et al. 2014, Carpentier et al. 2015). Unhatched egg content isotope ratios are equivalent to freshly laid egg yolk (Zbinden et al. 2011, Ceriani et al. 2014b). Sampling fresh egg yolk is a lethal sampling method and should be avoided if possible. We therefore support the recommendation by Ceriani et al. (2014b) that unhatched egg yolk should be sampled as a proxy for unobserved nesting females. Sampling for SIA can be intrusive and future work should take ethical concerns into consideration and determine whether it is warranted.

Conversion equations have been developed for many tissue-tissue relationships, which enables isotope ratios to be compared (see Table S2 in the Supplement for all available conversion equations). However, many studies that provide conversion equations state that they should be used with caution, as they are often derived from small sample sizes, with low coefficient of determination values, or weak correlations. Without performing controlled laboratory feeding studies, there are numerous factors that can influence isotopic differentiation between tissues (see Section 3.5), and these are unlikely to be consistent in all cases.

Using a standardised tissue type (as recommended above) would prevent the need for conversion equations and would enable direct comparisons between studies. If conversions are required, we recommend studies use values from tissues with the same biochemical mechanism (i.e. collagen is high in ${ }^{13} \mathrm{C}$ enriched glycine and therefore collagen has higher $\delta^{13} \mathrm{C}$ values in comparison to muscle) and they should only be done with tissue-types representing similar turnover time frames, e.g. scute and epidermis (Petitet \& Bugoni 2017), or unhatched egg content and epidermis (Ceriani et al. 2014b).

We support the recommendation by Belicka et al. (2012) and Ramos \& González-Solís (2012) that future studies should use a third forensic marker to provide greater power of inference of dietary estimations and geographical assignments. Only six marine turtle studies have thus far used a third marker, either $\delta^{34} \mathrm{~S}$ 
(Cardona et al. 2009, Belicka et al. 2012, Tucker et al. 2014, Bradshaw et al. 2017), trace elements (LópezCastro et al. 2013), or isotopes of trace elements, e.g. lead (López-Castro et al. 2014a). All of these techniques have limitations, for example climate and other conditions greatly affected the spatial and temporal variability of trace elements (Jickells et al. 2005). These limitations should be considered when designing studies and Ramos \& González-Solís (2012) recommend caution when simultaneously analysing multiple markers due to the differences in how they are integrated into a consumer's tissues (Bond 2010).

For a holistic understanding of marine turtle ecology, studies should, where possible, conduct concurrent complementary techniques such as stomach content analysis (e.g. Burkholder et al. 2011), satellite telemetry (e.g. Hatase et al. 2010), CSIA (e.g. Belicka et al. 2012, Peavey et al. 2017), and genetics (e.g. Watanabe et al. 2011). The need for complementary techniques is mirrored in seabird (Forero \& Hobson 2003), marine mammal (Newsome et al. 2010), and shark ecological research (Bird et al. 2018). We support Newsome et al. (2010) who recommend the use of time-depth recorders as well as satellite telemetry in marine mammal research to confirm the use of isotopic data as proxies for diet and habitat use.

For a more complete meta-analysis, the focus of future research should be on under-studied species and conducted globally across all species ranges. To understand a population as a whole, males should also be targeted in future studies, but we understand the difficulties of accessing males. We also recommend that, where possible, life stage and sex should be made clear in all publications. Studies over multiple years, rather than snap-shot studies, are also important to enable long-term shifts in population dynamics to be documented (e.g. Bradshaw et al. 2017, Ceriani et al. 2017). To fully understand the complexities of marine turtle ecology, data and findings should be combined at a global scale to facilitate meta-analytical approaches. This would also enable marine turtle species-specific isoscapes to be created. We encourage researchers to add their papers to the global inventory that we have initiated, by sending the appropriate data (under the specific column headings in the data archive at https://doi.org/ 10.1594/PANGAEA.892683) to the corresponding author for us to regularly update this open access global inventory. The open access means that this resource, and any future updates, will be available to all researchers, helping increase exposure of new studies, whilst also underpinning and accelerating new advances in the conservation of marine turtles.

\section{CONCLUSIONS}

This review confirms and details the wealth of ecological information gained from marine turtle stable isotope research. Clearly, large gaps in knowledge for several species and life stages exist, along with geographical bias in the distribution of studies. We have created a global inventory of published marine turtle stable isotope studies and data which can be continuously and easily revised as new data are collected. Recommendations, based on the extensive literature, are provided to guide future foci of ecology and conservation research of these important marine animals. Marine turtle stable isotope studies have helped reveal the complexity of marine turtle ecology, but we believe the full utility of stable isotopes is yet to be realised.

Acknowledgements. This research was conducted as part of J.C.H.'s PhD dissertation. J.C.H. is supported by a NERC GW4+ Doctoral Training Partnership studentship from the Natural Environment Research Council (NE/L002434/1). We thank the 3 anonymous reviewers and the editor, whose inputs have greatly improved the manuscript.

\section{LITERATURE CITED}

Agusa T, Takagi K, Miller TW, Kubota R, Anan Y, Iwata H, Tanabe S (2011) Intake and excretion of arsenicals in green (Chelonia mydas) and hawksbill turtles (Eretmochelys imbricata). Environ Chem 8:19-29

Allen CD, Lemons GE, Eguchi T, LeRoux RA and others (2013) Stable isotope analysis reveals migratory origin of loggerhead turtles in the Southern California Bight. Mar Ecol Prog Ser 472:275-285

Arthur KE, Boyle MC, Limpus CJ (2008) Ontogenetic changes in diet and habitat use in green sea turtle (Chelonia mydas) life history. Mar Ecol Prog Ser 362:303-311

Arthur KE, Kelez S, Larsen T, Choy CA, Popp BN (2014) Tracing the biosynthetic source of essential amino acids in marine turtles using $\delta^{13} \mathrm{C}$ fingerprints. Ecology 95: 1285-1293

Avens L, Goshe LR, Pajuelo M, Bjorndal KA and others (2013) Complementary skeletochronology and stable isotope analyses offer new insight into juvenile loggerhead sea turtle oceanic stage duration and growth dynamics. Mar Ecol Prog Ser 491:235-251

Avise JC (2007) Conservation genetics of marine turtles 10 years later. In: Hewitt D, Fulbright T (eds) Frontiers in wildlife science: linking ecological theory and management application. CRC Press, Boca Raton, FL, p 295-314

Barnes C, Jennings S, Polunin NV, Lancaster JE (2008) The importance of quantifying inherent variability when interpreting stable isotope field data. Oecologia 155: 227-235

Barrow LM, Bjorndal KA, Reich KJ (2008) Effects of preservation method on stable carbon and nitrogen isotope values. Physiol Biochem Zool 81:688-693

Belicka LL, Burkholder D, Fourqurean JW, Heithaus MR, 
Macko SA, Jaffé R (2012) Stable isotope and fatty acid biomarkers of seagrass, epiphytic, and algal organic matter to consumers in a pristine seagrass ecosystem. Mar Freshw Res 63:1085-1097

* Bergamo TF, Botta S, Copertino M (2016) Lipid extraction in stable isotope analyses of juvenile sea turtle skin and muscle. Aquat Biol 25:1-6

Bezerra MF, Lacerda LD, Rezende CE, Franco MAL and others (2015) Food preferences and Hg distribution in Chelonia mydas assessed by stable isotopes. Environ Pollut 206:236-246

Biasatti DM (2004) Stable carbon isotopic profiles of sea turtle humeri: implications for ecology and physiology. Palaeogeogr Palaeoclimatol Palaeoecol 206:203-216

Bird CS, Veríssimo A, Magozzi S, Abrantes KG and others (2018) A global perspective on the trophic geography of sharks. Nat Ecol Evol 2:299-305

Bjorndal KA (1997) Foraging ecology and nutrition of sea turtles. In: Lutz P, Musick J (eds) The biology of sea turtles, Vol 1. CRC Press, Boca Raton FL, p 199-231

Bjorndal KA, Bolten AB (2010) Hawksbill sea turtles in seagrass pastures: success in a peripheral habitat. Mar Biol 157:135-145

Bjorndal KA, Carr A (1989) Variation in clutch size and egg size in the green turtle nesting population at Tortuguero, Costa Rica. Herpetologica 45:181-189

Blasi MF, Tomassini L, Gelippi M, Careddu G, Insacco G, Polunin NVC (2018) Assessing resource use patterns of Mediterranean loggerhead sea turtles Caretta caretta (Linnaeus, 1758) through stable isotope analysis. Eur Zool J 85:71-87

Bond AL (2010) Relationships between stable isotopes and metal contaminants in feathers are spurious and biologically uninformative. Environ Pollut 158:1182-1184

Born EW, Outridge P, Riget FF, Hobson KA, Dietz R, Øien N, Haug T (2003) Population substructure of North Atlantic minke whales (Balaenoptera acutorostrata) inferred from regional variation of elemental and stable isotopic signatures in tissues. J Mar Syst 43:1-17

Boyle MD, Ebert DA, Cailliet GM (2012) Stable-isotope analysis of a deep-sea benthic-fish assemblage: evidence of an enriched benthic food web. J Fish Biol 80: 1485-1507

Bradshaw PJ, Broderick AC, Carreras C, Inger R and others (2017) Satellite tracking and stable isotope analysis highlight differential recruitment among foraging areas in green turtles. Mar Ecol Prog Ser 582:201-214

Broderick AC, Glen F, Godley BJ, Hays GC (2003) Variation in reproductive output of marine turtles. J Exp Mar Biol Ecol 288:95-109

Budge SM, Iverson SJ, Koopman HN (2006) Studying trophic ecology in marine ecosystems using fatty acids: a primer on analysis and interpretation. Mar Mamm Sci 22:759-801

Bugoni L, McGill RA, Furness RW (2010) The importance of pelagic longline fishery discards for a seabird community determined through stable isotope analysis. J Exp Mar Biol Ecol 391:190-200

Burgett CM, Burkholder DA, Coates KA, Fourqurean VL and others (2018) Ontogenetic diet shifts of green sea turtles (Chelonia mydas) in a mid-ocean developmental habitat. Mar Biol 165:33

Burkholder DA, Heithaus MR, Thomson JA, Fourqurean JW (2011) Diversity in trophic interactions of green sea turtles Chelonia mydas on a relatively pristine coastal foraging ground. Mar Ecol Prog Ser 439:277-293
Burton RK, Koch PL (1999) Isotopic tracking of foraging and long-distance migration in northeastern Pacific pinnipeds. Oecologia 119:578-585

* Cardona L, Aguilar A, Pazos L (2009) Delayed ontogenetic dietary shift and high levels of omnivory in green turtles (Chelonia mydas) from the NW coast of Africa. Mar Biol 156:1487-1495

Cardona L, Campos P, Levy Y, Demetropoulos A, Margaritoulis D (2010) Asynchrony between dietary and nutritional shifts during the ontogeny of green turtles (Chelonia mydas) in the Mediterranean. J Exp Mar Biol Ecol 393:83-89

* Cardona L, De Quevedo IÁ, Borrell A, Aguilar A (2012) Massive consumption of gelatinous plankton by Mediterranean apex predators. PLOS ONE 7:e31329

* Cardona L, Clusa M, Eder E, Demetropoulos A and others (2014) Distribution patterns and foraging ground productivity determine clutch size in Mediterranean loggerhead turtles. Mar Ecol Prog Ser 497:229-241

* Cardona L, Martínez-Iñigo L, Mateo R, González-Solís J (2015) The role of sardine as prey for pelagic predators in the western Mediterranean Sea assessed using stable isotopes and fatty acids. Mar Ecol Prog Ser 531:1-14

Cardona L, Martins S, Uterga R, Marco A (2017) Individual specialization and behavioral plasticity in a long-lived marine predator. J Exp Mar Biol Ecol 497:127-133

Carpena-Catoira C, Ortega-Ortiz CD, Elorriaga-Verplancken FR (2016) Isotopic effects of different preservation methods on scales of olive ridley sea turtles (Lepidochelys olivacea) from the Mexican Central Pacific. Rapid Commun Mass Spectrom 30:2480-2486

* Carpentier AS, Booth DT, Arthur KE, Limpus CJ (2015) Stable isotope relationships between mothers, eggs and hatchlings in loggerhead sea turtles Caretta caretta. Mar Biol 162:783-797

Casale P, Broderick AC, Camiñas JA, Cardona L and others (2018) Mediterranean sea turtles: current knowledge and priorities for conservation and research. Endang Species Res 36:229-267

Caut S, Angulo E, Courchamp F (2008a) Dietary shift of an invasive predator: rats, seabirds and sea turtles. J Appl Ecol 45:428-437

Caut S, Guirlet E, Angulo E, Das K, Girondot M (2008b) Isotope analysis reveals foraging area dichotomy for Atlantic leatherback turtles. PLOS ONE 3:e1845

* Caut S, Angulo E, Courchamp F (2009) Variation in discrimination factors $\left(\Delta^{15} \mathrm{~N}\right.$ and $\left.\Delta^{13} \mathrm{C}\right)$ : the effect of diet isotopic values and applications for diet reconstruction. J Appl Ecol 46:443-453

Ceriani SA, Roth JD, Evans DR, Weishampel JF, Ehrhart LM (2012) Inferring foraging areas of nesting loggerhead turtles using satellite telemetry and stable isotopes. PLOS ONE 7:e45335

Ceriani SA, Roth JD, Sasso CR, McClellan CM and others (2014a) Modeling and mapping isotopic patterns in the Northwest Atlantic derived from loggerhead sea turtles. Ecosphere 5:122

Ceriani SA, Roth JD, Ehrhart LM, Quintana-Ascencio PF, Weishampel JF (2014b) Developing a common currency for stable isotope analyses of nesting marine turtles. Mar Biol 161:2257-2268

Ceriani SA, Roth JD, Tucker AD, Evans DR and others (2015) Carry-over effects and foraging ground dynamics of a major loggerhead breeding aggregation. Mar Biol 162:1955-1968 
Ceriani SA, Weishampel JF, Ehrhart LM, Mansfield KL, Wunder MB (2017) Foraging and recruitment hotspot dynamics for the largest Atlantic loggerhead turtle rookery. Sci Rep 7:16894

* Cherel Y, Hobson KA, Guinet C, Vanpe C (2007) Stable isotopes document seasonal changes in trophic niches and winter foraging individual specialization in diving predators from the Southern Ocean. J Anim Ecol 76:826-836

Clusa M, Carreras C, Pascual M, Gaughran SJ and others (2016) Potential bycatch impact on distinct sea turtle populations is dependent on fishing ground rather than gear type in the Mediterranean Sea. Mar Biol 163:122

* Crawley KR, Hyndes GA, Vanderklift MA, Revill AT, Nichols PD (2009) Allochthonous brown algae are the primary food source for consumers in a temperate coastal environment. Mar Ecol Prog Ser 376:33-44

*De Troch M, Boeckx P, Cnudde C, Van Gansbeke D, Vanreusel A, Vincx M, Caramujo MJ (2012) Bioconversion of fatty acids at the basis of marine food webs: insights from a compound-specific stable isotope analysis. Mar Ecol Prog Ser 465:53-67

DeNiro MJ, Epstein S (1978) Influence of diet on the distribution of carbon isotopes in animals. Geochim Cosmochim Acta 42:495-506

* DeNiro MJ, Epstein S (1981) Influence of diet on the distribution of nitrogen isotopes in animals. Geochim Cosmochim Acta 45:341-351

"Netjen M, Sterling E, Gómez A (2015) Stable isotopes in barnacles as a tool to understand green sea turtle (Chelonia mydas) regional movement patterns. Biogeosciences 12: 7081-7086

* Di Beneditto APM, Siciliano S, Monteiro LR (2017) Herbivory level and niche breadth of juvenile green turtles (Chelonia mydas) in a tropical coastal area: insights from stable isotopes. Mar Biol 164:13

Dodge KL, Logan JM, Lutcavage ME (2011) Foraging ecology of leatherback sea turtles in the Western North Atlantic determined through multi-tissue stable isotope analyses. Mar Biol 158:2813-2824

* Dore JE, Brum JR, Tupas LM, Karl DM (2002) Seasonal and interannual variability in sources of nitrogen supporting export in the oligotrophic subtropical North Pacific Ocean. Limnol Oceanogr 47:1595-1607

Duffy DC, Jackson S (1986) Diet studies of seabirds: a review of methods. Colon Waterbirds 9:1-17

*Dujon AM, Schofield G, Lester RE, Papafitsoros K, Hays GC (2018) Complex movement patterns by foraging loggerhead sea turtles outside the breeding season identified using Argos-linked Fastloc-Global Positioning System. Mar Ecol 39:e12489

Eder E, Ceballos A, Martins S, Pérez-García H, Marín I, Marco A, Cardona L (2012) Foraging dichotomy in loggerhead sea turtles Caretta caretta off northwestern Africa. Mar Ecol Prog Ser 470:113-122

Evershed RP, Bull ID, Corr LT, Crossman ZM and others (2007) Compound-specific stable isotope analysis in ecological research. In: Michener R, Lajtha K (eds) Stable isotopes in ecology and environmental science, 2nd edn. Blackwell Publishing, Boston, MA, p 480-540

Ferreira RL, Ceia FR, Borges TC, Ramos JA, Bolten AB (2018) Foraging niche segregation between juvenile and adult hawksbill turtles (Eretmochelys imbricata) at Príncipe Island, West Africa. J Exp Mar Biol Ecol 498:1-7

Forero MG, Hobson KA (2003) Using stable isotopes of nitrogen and carbon to study seabird ecology: applications in the Mediterranean seabird community. Sci Mar 67(S2): 23-32

Frankel NS, Vander Zanden HB, Reich KJ, Williams KL, Bjorndal KA (2012) Mother-offspring stable isotope discrimination in loggerhead sea turtles Caretta caretta. Endang Species Res 17:133-138

Fukuoka T, Yamane M, Kinoshita C, Narazaki T and others (2016) The feeding habit of sea turtles influences their reaction to artificial marine debris. Sci Rep 6:28015

F Fuller WJ, Broderick AC, Hooker SK, Witt MJ, Godley BJ (2009) Insights into habitat utilization by green turtles (Chelonia mydas) during the inter-nesting period using animal-borne digital cameras. Mar Technol Soc J 43: 51-59

Gillis AJ, Ceriani SA, Seminoff JA, Fuentes MM (2018) Foraging ecology and diet selection of juvenile green turtles in the Bahamas: insights from stable isotope analysis and prey mapping. Mar Ecol Prog Ser 599:225-238

* Godley BJ, Thompson DR, Waldron S, Furness RW (1998) The trophic status of marine turtles as determined by stable isotope analysis. Mar Ecol Prog Ser 166:277-284

Godley BJ, Blumenthal JM, Broderick AC, Coyne MS, Godfrey MH, Hawkes LA, Witt MJ (2008) Satellite tracking of sea turtles: Where have we been and where do we go next? Endang Species Res 4:3-22

Goericke R, Fry B (1994) Variations of marine plankton $\delta^{13} \mathrm{C}$ with latitude, temperature, and dissolved $\mathrm{CO}_{2}$ in the world ocean. Global Biogeochem Cycles 8:85-90

González Carman VG, Botto F, Gaitán E, Albareda D, Campagna C, Mianzan H (2014) A jellyfish diet for the herbivorous green turtle Chelonia mydas in the temperate SW Atlantic. Mar Biol 161:339-349

*Goodman Hall AG, Avens L, Braun McNeill J, Wallace B, Goshe LR (2015) Inferring long-term foraging trends of individual juvenile loggerhead sea turtles using stable isotopes. Mar Ecol Prog Ser 537:265-276

Graham BS, Koch PL, Newsome SD, McMahon KW, Aurioles D (2010) Using isoscapes to trace the movements and foraging behavior of top predators in oceanic ecosystems. In: West J, Bowen G, Dawson T, Tu K (eds) Isoscapes. Springer, Dordrecht, p 299-318

* Gruber N, Keeling CD, Bacastow RB, Guenther PR and others (1999) Spatiotemporal patterns of carbon-13 in the global surface oceans and the oceanic Suess effect. Global Biogeochem Cycles 13:307-335

*Hamann M, Godfrey MH, Seminoff JA, Arthur K and others (2010) Global research priorities for sea turtles: informing management and conservation in the 21st century. Endang Species Res 11:245-269

Hancock JM, Vieira S, Jimenez V, Carvalho Rio J, Rebelo R (2018) Stable isotopes reveal dietary differences and site fidelity in juvenile green turtles foraging around São Tomé Island, West Central Africa. Mar Ecol Prog Ser 600: 165-177

Hannan LB, Roth JD, Ehrhart LM, Weishampel JF (2007) Dune vegetation fertilization by nesting sea turtles. Ecology 88:1053-1058

Hannides CCS, Popp BN, Landry MR, Graham BS (2009) Quantification of zooplankton trophic position in the North Pacific Subtropical Gyre using stable nitrogen isotopes. Limnol Oceanogr 54:50-61

*Harrington RR, Kennedy BP, Chamberlain CP, Blum JD, Folt CL (1998) ${ }^{15} \mathrm{~N}$ enrichment in agricultural catchments: field patterns and applications to tracking Atlantic salmon (Salmo salar). Chem Geol 147:281-294 
Harrison XA, Blount JD, Inger R, Norris DR, Bearhop S (2011) Carry-over effects as drivers of fitness differences in animals. J Anim Ecol 80:4-18

Hatase H, Omuta K (2018) Nest site selection in loggerhead sea turtles that use different foraging areas: Do less fecund oceanic foragers nest at safer sites? J Zool (Lond) 305:232-239

Hatase H, Takai N, Matsuzawa Y, Sakamoto W and others (2002) Size-related differences in feeding habitat use of adult female loggerhead turtles Caretta caretta around Japan determined by stable isotope analyses and satellite telemetry. Mar Ecol Prog Ser 233:273-281

*Hatase H, Sato K, Yamaguchi M, Takahashi K, Tsukamoto K (2006) Individual variation in feeding habitat use by adult female green sea turtles (Chelonia mydas): Are they obligately neritic herbivores? Oecologia 149:52-64

Hatase H, Omuta K, Tsukamoto K (2010) Oceanic residents, neritic migrants: a possible mechanism underlying foraging dichotomy in adult female loggerhead turtles (Caretta caretta). Mar Biol 157:1337-1342

Hatase H, Omuta K, Tsukamoto K (2013) A mechanism that maintains alternative life histories in a loggerhead sea turtle population. Ecology 94:2583-2594

Hatase H, Omuta K, Komatsu T (2014) Do loggerhead turtle (Caretta caretta) eggs vary with alternative foraging tactics? J Exp Mar Biol Ecol 455:56-61

Hatase H, Omuta K, Komatsu T (2015) Loggerhead turtle (Caretta caretta) offspring size does not vary with maternal alternative foraging behaviors: support for their phenotypic plasticity. Mar Biol 162:1567-1578

Hatase H, Omuta K, Itou K, Komatsu T (2018) Effect of maternal foraging habitat on offspring quality in the loggerhead sea turtle (Caretta caretta). Ecol Evol 8: 3543-3555

Hays GC, Hobson VJ, Metcalfe JD, Righton D, Sims DW (2006) Flexible foraging movements of leatherback turtles across the North Atlantic Ocean. Ecology 87: 2647-2656

Hays GC, Fossette S, Katselidis KA, Schofield G, Gravenor MB (2010) Breeding periodicity for male sea turtles operational sex ratios, and implications in the face of climate change. Conserv Biol 24:1636-1643

Healy K, Guillerme T, Kelly SBA, Inger R, Bearhop S, Jackson AL (2018) SIDER: an R package for predicting trophic discrimination factors of consumers based on their ecology and phylogenetic relatedness. Ecography 41:1393-1400

*Hedges JI, Baldock JA, Gélinas Y, Lee C, Peterson M, Wakeham SG (2001) Evidence for non-selective preservation of organic matter in sinking marine particles. Nature 409:801

'Heithaus MR, McLash JJ, Frid A, Dill LM, Marshall GJ (2002) Novel insights into green sea turtle behaviour using animal-borne video cameras. J Mar Biol Assoc UK 82:1049-1050

Hetherington ED, Seminoff JA, Dutton PH, Robison LC, Popp BN, Kurle CM (2018) Long-term trends in the foraging ecology and habitat use of an endangered species: an isotopic perspective. Oecologia 188:1273-1285

*Hinga KR, Arthur MA, Pilson MEQ, Whitaker D (1994) Carbon isotope fractionation by marine phytoplankton in culture: the effects of $\mathrm{CO}_{2}$ concentration, $\mathrm{pH}$, temperature, and species. Global Biogeochem Cycles 8:91-102

Hobson KA (1987) Use of stable-carbon isotope analysis to estimate marine and terrestrial protein content in gull diets. Can J Zool 65:1210-1213

Howell LN, Reich KJ, Shaver DJ, Landry AM Jr, Gorga CC (2016) Ontogenetic shifts in diet and habitat of juvenile green sea turtles in the northwestern Gulf of Mexico. Mar Ecol Prog Ser 559:217-229

Iverson SJ, Field C, Bowen WD, Blanchard W (2004) Quantitative fatty acid signature analysis: a new method of estimating predator diets. Ecol Monogr 74:211-235

Jackson AL, Inger R, Parnell AC, Bearhop S (2011) Comparing isotopic niche widths among and within communities: SIBER - Stable Isotope Bayesian Ellipses in R. J Anim Ecol 80:595-602

James MC, Eckert SA, Myers RA (2005) Migratory and reproductive movements of male leatherback turtles (Dermochelys coriacea). Mar Biol 147:845-853

Jaschinski S, Brepohl DC, Sommer U (2008) Carbon sources and trophic structure in an eelgrass Zostera marina bed, based on stable isotope and fatty acid analyses. Mar Ecol Prog Ser 358:103-114

Jeffers VF, Godley BJ (2016) Satellite tracking in sea turtles: How do we find our way to the conservation dividends? Biol Conserv 199:172-184

Jickells TD, An ZS, Andersen KK, Baker AR and others (2005) Global iron connections between desert dust, ocean biogeochemistry, and climate. Science 308:67-71

Kaufman TJ, Pajuelo M, Bjorndal KA, Bolten AB, Pfaller JB, Williams KL, Vander Zanden HB (2014) Mother-egg stable isotope conversions and effects of lipid extraction and ethanol preservation on loggerhead eggs. Conserv Physiol 2:cou049

Killingley JS, Lutcavage M (1983) Loggerhead turtle movements reconstructed from ${ }^{18} \mathrm{O}$ and ${ }^{13} \mathrm{C}$ profiles from commensal barnacle shells. Estuar Coast Shelf Sci 16: 345-349

Komoroske LM, Jensen MP, Stewart KR, Shamblin BM, Dutton PH (2017) Advances in the application of genetics in marine turtle biology and conservation. Front Mar Sci 4: 156

Krahn MM, Pitman RL, Burrows DG, Herman DP, Pearce RW (2008) Use of chemical tracers to assess diet and persistent organic pollutants in Antarctic type C killer whales. Mar Mamm Sci 24:643-663

Larsen T, Taylor DL, Leigh MB, O'Brien DM (2009) Stable isotope fingerprinting: a novel method for identifying plant, fungal, or bacterial origins of amino acids. Ecology 90:3526-3535

KLarsen T, Wooller MJ, Fogel ML, O'Brien DM (2012) Can amino acid carbon isotope ratios distinguish primary producers in a mangrove ecosystem? Rapid Commun Mass Spectrom 26:1541-1548

Larsen T, Ventura M, Andersen N, O'Brien DM, Piatkowski U, McCarthy MD (2013) Tracing carbon sources through aquatic and terrestrial food webs using amino acid stable isotope fingerprinting. PLOS ONE 8:e73441

Layman CA, Arrington DA, Montaña CG, Post DM (2007) Can stable isotope ratios provide for community-wide measures of trophic structure? Ecology 88:42-8

Layman CA, Araujo MS, Boucek R, Hammerschlag-Peyer CM and others (2012) Applying stable isotopes to examine food-web structure: an overview of analytical tools. Biol Rev Camb Philos Soc 87:545-562

* Le Gouvello DZM, Nel R, Harris LR, Bezuidenhout K, Woodborne S (2017) Identifying potential pathways for turtlederived nutrients cycling through beach ecosystems. Mar Ecol Prog Ser 583:49-62 
Lemons G, Lewison R, Komoroske L, Gaos A and others (2011) Trophic ecology of green sea turtles in a highly urbanized bay: insights from stable isotopes and mixing models. J Exp Mar Biol Ecol 405:25-32

Lemons GE, Eguchi T, Lyon BN, LeRoux R, Seminoff JA (2012) Effects of blood anticoagulants on stable isotope values of sea turtle blood tissue. Aquat Biol 14:201-206

Limpus CJ, Miller JD, Paramenter CJ, Reimer D, McLachlan N, Webb R (1992) Migration of green (Chelonia mydas) and loggerhead (Caretta caretta) turtles to and from eastern Australian rookeries. Wildl Res 19:347-357

López-Castro MC, Bjorndal KA, Kamenov GD, Zenil-Ferguson R, Bolten AB (2013) Sea turtle population structure and connections between oceanic and neritic foraging areas in the Atlantic revealed through trace elements. Mar Ecol Prog Ser 490:233-246

López-Castro MC, Bjorndal KA, Kamenov GD, Bolten AB (2014a) Identifying oceanic foraging grounds of sea turtles in the Atlantic using lead isotopes. Mar Biol 161: 2269-2278

López-Castro MC, Bjorndal KA, Bolten AB (2014b) Evaluation of scute thickness to infer life history records in the carapace of green and loggerhead turtles. Endang Species Res 24:191-196

Madigan DJ, Baumann Z, Snodgrass OE, Dewar H and others (2017) Assessing Fukushima-derived radiocesium in migratory Pacific predators. Environ Sci Technol 51: 8962-8971

Magozzi S, Yool A, Vander Zanden HB, Wunder MB, Trueman CN (2017) Using ocean models to predict spatial and temporal variation in marine carbon isotopes. Ecosphere 8:e01763

Maljkovi A, Côté IM (2011) Effects of tourism-related provisioning on the trophic signatures and movement patterns of an apex predator, the Caribbean reef shark. Biol Conserv 144:859-865

Martínez del Rio C, Wolf N, Carleton SA, Gannes LZ (2009) Isotopic ecology ten years after a call for more laboratory experiments. Biol Rev Camb Philos Soc 84:91-111

Matich P, Heithaus MR, Layman CA (2011) Contrasting patterns of individual specialization and trophic coupling in two marine apex predators. J Anim Ecol 80:294-305

McClellan CM, Braun-McNeill J, Avens L, Wallace BP, Read AJ (2010) Stable isotopes confirm a foraging dichotomy in juvenile loggerhead sea turtles. J Exp Mar Biol Ecol 387:44-51

McClelland JW, Montoya JP (2002) Trophic relationships and the nitrogen isotopic composition of amino acids in plankton. Ecology 83:2173-2180

McKinney RA, Lake JL, Charpentier MA, Ryba S (2002) Using mussel isotope ratios to assess anthropogenic nitrogen inputs to freshwater ecosystems. Environ Monit Assess 74:167-192

McMahon KW, Hamady LL, Thorrold SR (2013) A review of ecogeochemistry approaches to estimating movements of marine animals. Limnol Oceanogr 58:697-714

Medeiros L, da Silveira Monteiro D, Petitet R, Bugoni L (2015) Effects of lipid extraction on the isotopic values of sea turtle bone collagen. Aquat Biol 23:191-199

Miller JD (1997) Reproduction in sea turtles. In: Lutz PL, Musick JA (eds) The biology of sea turtles, Vol 1. CRC Press, Boca Raton, FL, p 51-81

Minagawa M, Wada E (1984) Stepwise enrichment of ${ }^{15} \mathrm{~N}$ along food chains: further evidence and the relation between $\delta^{15} \mathrm{~N}$ and animal age. Geochim Cosmochim
Acta 48:1135-1140

Moll RJ, Millspaugh JJ, Beringer J, Sartwell J, He Z (2007) A new 'view' of ecology and conservation through animalborne video systems. Trends Ecol Evol 22:660-668

Moncada FG, Koike H, Espinosa G, Manolis SC and others (1997) Annex 8: Movement and population integrity. In: An annotated transfer of the Cuban population of hawksbill turtles (Eretomochelys imbricafa) from CITES appendix I to II. CITES, Lausanne, p 47-57

Montoya JP (2007) Natural abundance of ${ }^{15} \mathrm{~N}$ in marine planktonic ecosystems. In: Michener R, Lajtha K (eds) Stable isotopes in ecology and environmental science, 2nd edn. Blackwell, Malden, MA, p 176-201

Montoya JP, Carpenter EJ, Capone DG (2002) Nitrogen fixation and nitrogen isotope abundances in zooplankton of the oligotrophic North Atlantic. Limnol Oceanogr 47: $1617-1628$

*Monzón-Argüello C, Cardona L, Calabuig P, Camacho M and others (2018) Supplemental feeding and other anthropogenic threats to green turtles (Chelonia mydas) in the Canary Islands. Sci Total Environ 621:1000-1011

Moore JW, Semmens BX (2008) Incorporating uncertainty and prior information into stable isotope mixing models. Ecol Lett 11:470-480

Musick JA, Limpus CJ (1997) Habitat utilization and migration in juvenile sea turtles. In: Lutz P, Musick J (eds) The biology of sea turtles, Vol 1. CRC Press, Boca Raton, FL, p 137-163

Narazaki T, Sato K, Abernathy KJ, Marshall GJ, Miyazaki N (2013) Loggerhead turtles (Caretta caretta) use vision to forage on gelatinous prey in mid-water. PLOS ONE 8: e66043

Newsome SD, Martinez del Rio C, Bearhop S, Phillips DL (2007) A niche for isotopic ecology. Front Ecol Environ 5: 429-436

Newsome SD, Etnier MA, Monson DH, Fogel ML (2009) Retrospective characterization of ontogenetic shifts in killer whale diets via $\delta^{13} \mathrm{C}$ and $\delta^{15} \mathrm{~N}$ analysis of teeth. Mar Ecol Prog Ser 374:229-242

Newsome SD, Clementz MT, Koch PL (2010) Using stable isotope biogeochemistry to study marine mammal ecology. Mar Mamm Sci 26:509-572

Nichols WJ, Resendiz A, Seminoff JA, Resendiz B (2000) Transpacific migration of a loggerhead turtle monitored by satellite telemetry. Bull Mar Sci 67:937-947

* O'Brien DM, Fogel ML, Boggs CL (2002) Renewable and nonrenewable resources: amino acid turnover and allocation to reproduction in Lepidoptera. Proc Natl Acad Sci USA 99:4413-4418

Ogden JC, Robinson L, Whitlock K, Daganhardt H, Cebula R (1983) Diel foraging patterns in juvenile green turtles (Chelonia mydas L.) in St. Croix United States Virgin Islands. J Exp Mar Biol Ecol 66:199-205

*Páez-Osuna F, Calderón-Campuzano MF, Soto-Jiménez MF, Ruelas-Inzunza JR (2010) Lead in blood and eggs of the sea turtle, Lepidochelys olivacea, from the Eastern Pacific: concentration, isotopic composition and maternal transfer. Mar Pollut Bull 60:433-439

Pajuelo M, Bjorndal KA, Alfaro-Shigueto J, Seminoff JA, Mangel JC, Bolten AB (2010) Stable isotope variation in loggerhead turtles reveals Pacific-Atlantic oceanographic differences. Mar Ecol Prog Ser 417:277-285

Pajuelo M, Bjorndal KA, Reich KJ, Vander Zanden HB, Hawkes LA, Bolten AB (2012a) Assignment of nesting loggerhead turtles to their foraging areas in the North- 
west Atlantic using stable isotopes. Ecosphere 3:89

Pajuelo M, Bjorndal KA, Reich KJ, Arendt MD, Bolten AB (2012b) Distribution of foraging habitats of male loggerhead turtles (Caretta caretta) as revealed by stable isotopes and satellite telemetry. Mar Biol 159:1255-1267

*Pajuelo M, Bjorndal KA, Arendt MD, Foley AM, Schroeder BA, Witherington BE, Bolten AB (2016) Long-term resource use and foraging specialization in male loggerhead turtles. Mar Biol 163:235

Pancost RD, Freeman KH, Wakeham SG, Robertson CY (1997) Controls on carbon isotope fractionation by diatoms in the Peru upwelling region. Geochim Cosmochim Acta 61:4983-4991

Parnell AC, Inger R, Bearhop S, Jackson AL (2010) Source partitioning using stable isotopes: coping with too much variation. PLOS ONE 5:e9672

*Payo-Payo A, Ruiz B, Cardona L, Borrell A (2013) Effect of tissue decomposition on stable isotope signatures of striped dolphins Stenella coeruleoalba and loggerhead sea turtles Caretta caretta. Aquat Biol 18:141-147

Pearson RM, van de Merwe JP, Limpus CJ, Connolly RM (2017) Realignment of sea turtle isotope studies needed to match conservation priorities. Mar Ecol Prog Ser 583: 259-271

* Peavey LE, Popp BN, Pitman RL, Gaines SD, Arthur KE, Kelez S, Seminoff JA (2017) Opportunism on the high seas: foraging ecology of olive ridley turtles in the eastern Pacific Ocean. Front Mar Sci 4:348

Peterson BJ, Fry B (1987) Stable isotopes in ecosystem studies. Annu Rev Ecol Syst 18:293-320

* Petitet R, Bugoni L (2017) High habitat use plasticity by female olive ridley sea turtles (Lepidochelys olivacea) revealed by stable isotope analysis in multiple tissues. Mar Biol 164:134

Phillips DL, Gregg JW (2003) Source partitioning using stable isotopes: coping with too many sources. Oecologia 136:261-269

Plotkin P (2003) Adult migrations and habitat use. In: Lutz $\mathrm{P}_{\text {, }}$ Musick J, Wyneken J (eds) The biology of sea turtles, Vol 2. CRC Press, Boca Raton, FL, p 225-241

Popp BN, Laws EA, Bidigare RR, Dore JE, Hanson KL, Wakeham SG (1998) Effect of phytoplankton cell geometry on carbon isotopic fractionation. Geochim Cosmochim Acta 62:69-77

Post DM (2002) Using stable isotopes to estimate trophic position: models, methods, and assumptions. Ecology 83: 703-718

Post DM, Layman CA, Arrington DA, Takimoto G, Quattrochi J, Montana CG (2007) Getting to the fat of the matter: models, methods and assumptions for dealing with lipids in stable isotope analyses. Oecologia 152:179-189

Price JT, Pfaller JB, Vander Zanden HB, Williams KL, Bolten AB, Bjorndal KA (2017) Foraging area, not trophic position, is linked to head size variation in adult female loggerhead turtles. J Zool (Lond) 302:279-287

Prior B, Booth DT, Limpus CJ (2016) Investigating diet and diet switching in green turtles (Chelonia mydas). Aust J Zool 63:365-375

*Quezada-Romegialli C, Jackson AL, Hayden B, Kahilainen KK, Lopes C, Harrod C (2018) tRophicPosition, an R package for the Bayesian estimation of trophic position from consumer stable isotope ratios. Methods Ecol Evol 9:1592-1599

Ramirez MD, Avens L, Seminoff JA, Goshe LR, Heppell SS (2015) Patterns of loggerhead turtle ontogenetic shifts revealed through isotopic analysis of annual skeletal growth increments. Ecosphere 6:244

Ramirez MD, Avens L, Seminoff JA, Goshe LR, Heppell SS (2017) Growth dynamics of juvenile loggerhead sea turtles undergoing an ontogenetic habitat shift. Oecologia 183:1087-1099

Ramos R, González-Solís J (2012) Trace me if you can: the use of intrinsic biogeochemical markers in marine top predators. Front Ecol Environ 10:258-266

Rees AF, Alfaro-Shigueto J, Barata PCR, Bjorndal KA and others (2016) Are we working towards global research priorities for management and conservation of sea turtles? Endang Species Res 31:337-382

Reich KJ, Bjorndal KA, Bolten AB (2007) The 'lost years' of green turtles: using stable isotopes to study cryptic lifestages. Biol Lett 3:712-714

Reich KJ, Bjorndal KA, Martínez Del Rio C (2008) Effects of growth and tissue type on the kinetics of ${ }^{13} \mathrm{C}$ and ${ }^{15} \mathrm{~N}$ incorporation in a rapidly growing ectotherm. Oecologia 155:651-663

Reich KJ, Bjorndal KA, Frick MG, Witherington BE, Johnson C, Bolten AB (2010) Polymodal foraging in adult female loggerheads (Caretta caretta). Mar Biol 157:113-121

*Reich KJ, López-Castro MC, Shaver DJ, Iseton C, Hart KM, Hooper MJ, Schmitt CJ (2017) $\delta^{13} C$ and $\delta^{15} \mathrm{~N}$ in the endangered Kemp's ridley sea turtle Lepidochelys kempii after the Deepwater Horizon oil spill. Endang Species Res 33:281-289

Revelles M, Cardona L, Aguilar A, Fernández G (2007a) The diet of pelagic loggerhead sea turtles (Caretta caretta) off the Balearic archipelago (western Mediterranean): relevance of long-line baits. J Mar Biol Assoc UK 87:805-813

Kevelles M, Cardona L, Aguilar A, Borrell A, Fernández G, San Félix M (2007b) Stable C and N isotope concentration in several tissues of the loggerhead sea turtle Caretta caretta from the western Mediterranean and dietary implications. Sci Mar 71:87-93

Robinson NJ, Morreale SJ, Nel R, Paladino FV (2016) Coastal leatherback turtles reveal conservation hotspot. Sci Rep 6:37851

*Roscales JL, Gómez-Díaz E, Neves V, González-Solís J (2011) Trophic versus geographic structure in stable isotope signatures of pelagic seabirds breeding in the northeast Atlantic. Mar Ecol Prog Ser 434:1-13

Rubenstein DR, Hobson KA (2004) From birds to butterflies: animal movement patterns and stable isotopes. Trends Ecol Evol 19:256-263

Saba VS, Santidrián-Tomillo P, Reina RD, Spotila JR, Musick JA, Evans DA, Paladino FV (2007) The effect of the El Niño Southern Oscillation on the reproductive frequency of eastern Pacific leatherback turtles. J Appl Ecol 44: 395-404

* Sampson L, Giraldo A, Payán LF, Amorocho DF, Ramos MA, Seminoff JA (2017) Trophic ecology of green turtle Chelonia mydas juveniles in the Colombian Pacific. J Mar Biol Assoc UK 98:1817-1829

Santos RG, Martins AS, da Nobrega Farias J, Horta PA and others (2011) Coastal habitat degradation and green sea turtle diets in Southeastern Brazil. Mar Pollut Bull 62: 1297-1302

Schell DM, Saupe SM, Haubenstock N (1989) Bowhead whale (Balaena mysticetus) growth and feeding as estimated by $\delta^{13} \mathrm{C}$ techniques. Mar Biol 103:433-443

Schmittner A, Somes CJ (2016) Complementary constraints from carbon $\left({ }^{13} \mathrm{C}\right)$ and nitrogen $\left({ }^{15} \mathrm{~N}\right)$ isotopes on the gla- 
cial ocean's soft-tissue biological pump. Paleoceanogr Paleoclimatol 31:669-693

Schofield G, Katselidis KA, Dimopoulos P, Pantis JD, Hays GC (2006) Behaviour analysis of the loggerhead sea turtle Caretta caretta from direct in-water observation. Endang Species Res 2:71-79

Seaborn GT, Moore MK, Balazs GH (2005) Depot fatty acid composition in immature green turtles (Chelonia mydas) residing at two near-shore foraging areas in the Hawaiian Islands. Comp Biochem Physiol B Biochem Mol Biol 140:183-195

Seminoff JA, Resendiz A, Nichols WJ (2002) Diet of East Pacific green turtles (Chelonia mydas) in the central Gulf of California, Mexico. J Herpetol 36:447-453

Seminoff JA, Jones TT, Eguchi T, Jones DR, Dutton PH (2006a) Stable isotope discrimination $\left(\delta^{13} \mathrm{C}\right.$ and $\left.\delta^{15} \mathrm{~N}\right)$ between soft tissues of the green sea turtle Chelonia mydas and its diet. Mar Ecol Prog Ser 308:271-278

Seminoff JA, Jones TT, Marshall GJ (2006b) Underwater behaviour of green turtles monitored with video-timedepth recorders: What's missing from dive profiles? Mar Ecol Prog Ser 322:269-280

Seminoff JA, Zárate P, Coyne M, Foley DG, Parker D, Lyon BN, Dutton PH (2008) Post-nesting migrations of Galápagos green turtles Chelonia mydas in relation to oceanographic conditions: integrating satellite telemetry with remotely sensed ocean data. Endang Species Res 4: 57-72

Seminoff JA, Jones TT, Eguchi T, Hastings M, Jones DR (2009) Stable carbon and nitrogen isotope discrimination in soft tissues of the leatherback turtle (Dermochelys coriacea): insights for trophic studies of marine turtles. J Exp Mar Biol Ecol 381:33-41

Seminoff JA, Benson SR, Arthur KE, Eguchi T, Dutton PH, Tapilatu RF, Popp BN (2012) Stable isotope tracking of endangered sea turtles: validation with satellite telemetry and $\delta^{15} \mathrm{~N}$ analysis of amino acids. PLOS ONE 7: e37403

Shamblin BM, Dutton PH, Shaver DJ, Bagley DA and others (2017) Mexican origins for the Texas green turtle foraging aggregation: a cautionary tale of incomplete baselines and poor marker resolution. J Exp Mar Biol Ecol 488:111-120

Shiffman DS, Gallagher AJ, Boyle MD, HammerschlagPeyer CM, Hammerschlag N (2012) Stable isotope analysis as a tool for elasmobranch conservation research: a primer for non-specialists. Mar Freshw Res 63:635-643

Shiffman DS, Gallagher AJ, Boyle MD, HammerschlagPeyer CM, Hammerschlag N (2012) Stable isotope analysis as a tool for elasmobranch conservation research: a primer for non-specialists. Mar Freshw Res 63:635-43

Shillinger GL, Palacios DM, Bailey H, Bograd SJ and others (2008) Persistent leatherback turtle migrations present opportunities for conservation. PLOS Biol 6:e171

Shimada T, Aoki S, Kameda K, Hazel J, Reich K, Kamezaki N (2014) Site fidelity, ontogenetic shift and diet composition of green turtles Chelonia mydas in Japan inferred from stable isotope analysis. Endang Species Res 25: 151-164

Snover ML (2008) Ontogenetic habitat shifts in marine organisms: influencing factors and the impact of climate variability. Bull Mar Sci 83:53-67

"Snover ML, Avens L, Hohn AA (2007) Back-calculating length from skeletal growth marks in loggerhead sea turtles Caretta caretta. Endang Species Res 3:95-104
Snover ML, Hohn AA, Crowder LB, Macko SA (2010) Combining stable isotopes and skeletal growth marks to detect habitat shifts in juvenile loggerhead sea turtles Caretta caretta. Endang Species Res 13:25-31

Somes CJ, Schmittner A, Galbraith ED, Lehmann MF and others (2010) Simulating the global distribution of nitrogen isotopes in the ocean. Global Biogeochem Cycles 24: GB4019

Stock B, Semmens B (2016) MixSIAR (GUI user manual), version 31. https://github.com/brianstock/MixSIAR

Sullivan MJ, Moncreiff CA (1990) Edaphic algae are an important component of salt marsh food-webs: evidence from multiple stable isotope analyses. Mar Ecol Prog Ser 62:149-159

Tagliabue A, Bopp L (2008) Towards understanding global variability in ocean carbon-13. Global Biogeochem Cycles 22:GB1025

* Thomson JA, Heithaus MR, Burkholder DA, Vaudo JJ, Wirsing AJ, Dill LM (2012) Site specialists, diet generalists? Isotopic variation, site fidelity, and foraging by loggerhead turtles in Shark Bay, Western Australia. Mar Ecol Prog Ser 453:213-226

Thomson JA, Whitman ER, Garcia-Rojas MI, Bellgrove A, Ekins M, Hays GC, Heithaus MR (2018) Individual specialization in a migratory grazer reflects long-term diet selectivity on a foraging ground: implications for isotopebased tracking. Oecologia 188:429-439

*Tomy GT, Budakowski W, Halldorson T, Helm PA and others (2004) Fluorinated organic compounds in an eastern Arctic marine food web. Environ Sci Technol 38: 6475-6481

Trueman CN, MacKenzie KM, St John Glew K (2017) Stable isotope-based location in a shelf sea setting: accuracy and precision are comparable to light-based location methods. Methods Ecol Evol 8:232-240

Tucker AD, MacDonald BD, Seminoff JA (2014) Foraging site fidelity and stable isotope values of loggerhead turtles tracked in the Gulf of Mexico and northwest Caribbean. Mar Ecol Prog Ser 502:267-279

Turner Tomaszewicz CN, Seminoff JA, Peckham SH, Avens L, Kurle CM (2017a) Intrapopulation variability in the timing of ontogenetic habitat shifts in sea turtles revealed using $\delta^{15} \mathrm{~N}$ values from bone growth rings. J Anim Ecol 86:694-704

Turner Tomaszewicz CN, Seminoff JA, Price M, Kurle CM (2017b) Stable isotope discrimination factors and betweentissue isotope comparisons for bone and skin from captive and wild green sea turtles (Chelonia mydas). Rapid Commun Mass Spectrom 31:1903-1914

Turner Tomaszewicz CN, Seminoff JA, Avens L, Goshe LR, Rguez-Baron JM, Peckham SH, Kurle CM (2018) Expanding the coastal forager paradigm: long-term pelagic habitat use by green turtles Chelonia mydas in the eastern Pacific Ocean. Mar Ecol Prog Ser 587:217-234

van Schingen M, Ziegler T, Boner M, Streit B, Nguyen TQ, Crook V, Ziegler S (2016) Can isotope markers differentiate between wild and captive reptile populations? A case study based on crocodile lizards (Shinisaurus crocodilurus) from Vietnam. Glob Ecol Conserv 6:232-241

Vander Zanden HB, Bjorndal KA, Reich KJ, Bolten AB (2010) Individual specialists in a generalist population: results from a long-term stable isotope series. Biol Lett 6: 711-714

Vander Zanden HB, Bjorndal KA, Mustin W, Ponciano JM, Bolten AB (2012) Inherent variation in stable isotope val- 
ues and discrimination factors in two life stages of green turtles. Physiol Biochem Zool 85:431-441

Vander Zanden HB, Arthur KE, Bolten AB, Popp BN and others (2013a) Trophic ecology of a green turtle breeding population. Mar Ecol Prog Ser 476:237-249

Vander Zanden HB, Bjorndal KA, Bolten AB (2013b) Temporal consistency and individual specialization in resource use by green turtles in successive life stages. Oecologia 173:767-777

Vander Zanden HB, Pfaller JB, Reich KJ, Pajuelo M and others (2014) Foraging areas differentially affect reproductive output and interpretation of trends in abundance of loggerhead turtles. Mar Biol 161:585-598

Vander Zanden HB, Tucker AD, Hart KM, Lamont MM and others (2015) Determining origin in a migratory marine vertebrate: a novel method to integrate stable isotopes and satellite tracking. Ecol Appl 25:320-335

* Vander Zanden HB, Bolten AB, Tucker AD, Hart KM and others (2016) Biomarkers reveal sea turtles remained in oiled areas following the Deepwater Horizon oil spill. Ecol Appl 26:2145-2155

Vélez-Rubio GM, Cardona L, López-Mendilaharsu M, Souza GM, Carranza A, González-Paredes D, Tomás J (2016) Ontogenetic dietary changes of green turtles (Chelonia mydas) in the temperate southwestern Atlantic. Mar Biol 163:57

*Vélez-Rubio GM, Cardona L, López-Mendilaharsu M, Souza GM and others (2018) Pre and post-settlement movements of juvenile green turtles in the Southwestern Atlantic Ocean. J Exp Mar Biol Ecol 501:36-45

*Vogel JC, Eglington B, Auret JM (1990) Isotope fingerprints in elephant bone and ivory. Nature 346:747

Voss M, Dippner JW, Montoya JP (2001) Nitrogen isotope patterns in the oxygen-deficient waters of the Eastern Tropical North Pacific Ocean. Deep Sea Res I 48: 1905-1921

Editorial responsibility: Keith Hobson, London, Ontario, Canada
Walker JL, Potter CW, Macko SA (1999) The diets of modern and historic bottlenose dolphin populations reflected through stable isotopes. Mar Mamm Sci 15:335-350

Wallace BP, Seminoff JA, Kilham SS, Spotila JR, Dutton PH (2006) Leatherback turtles as oceanographic indicators: stable isotope analyses reveal a trophic dichotomy between ocean basins. Mar Biol 149:953-960

Wallace BP, Avens L, Braun-McNeill J, McClellan CM (2009) The diet composition of immature loggerheads: insights on trophic niche, growth rates, and fisheries interactions. J Exp Mar Biol Ecol 373:50-57

Wallace BP, Schumacher J, Seminoff JA, James MC (2014) Biological and environmental influences on the trophic ecology of leatherback turtles in the northwest Atlantic Ocean. Mar Biol 161:1711-1724

Watanabe KK, Hatase H, Kinoshita M, Omuta K and others (2011) Population structure of the loggerhead turtle Caretta caretta, a large marine carnivore that exhibits alternative foraging behaviors. Mar Ecol Prog Ser 424:273-283

Wibbels T (2003) Critical approaches to sex determination in sea turtles. In: Lutz P, Musick J, Wyneken J (eds) The biology of sea turtles, Vol 2. CRC Press, Boca Raton, FL, p 103-134

Williams NC, Bjorndal KA, Lamont MM, Carthy RR (2014) Winter diets of immature green turtles (Chelonia mydas) on a northern feeding ground: integrating stomach contents and stable isotope analyses. Estuaries Coasts 37: 986-994

Wolf N, Carleton SA, Martínez del Rio C (2009) Ten years of experimental animal isotopic ecology. Funct Ecol 23: $17-26$

Zbinden JA, Bearhop S, Bradshaw P, Gill B, Margaritoulis D, Newton J, Godley BJ (2011) Migratory dichotomy and associated phenotypic variation in marine turtles revealed by satellite tracking and stable isotope analysis. Mar Ecol Prog Ser 421:291-302

Submitted: July 23, 2018; Accepted: February 7, 2019 Proofs received from author(s): March 15, 2019 